\title{
Pliocene-Pleistocene Radiolarian Events and Magnetostratigraphic Calibrations for the Tropical Indian Ocean ${ }^{\mathbf{1 , 2}}$
}

\author{
DAVID A. JOHNSON ${ }^{3}$, DAVID A. SCHNEIDER ${ }^{4}$, CATHERINE A. NIGRINI $^{5}$, JEAN PIERRE \\ CAULET $^{6}$ and DENNIS V. KENT ${ }^{4}$ \\ ${ }^{3}$ Woods Hole Oceanographic Institution, Woods Hole, MA 02543 (U.S.A.) \\ ${ }^{4}$ Lamont-Doherty Geological Observatory, Palisades, NY 10964 (U.S.A.) \\ ${ }^{5} 510$ Papyrus Drive, La Habra Heights, CA, 90631 (U.S.A.) \\ ${ }^{6}$ Laboratoire de géologie, Muséum national d'histoire naturelle, 43 rue de Buffon, 75005 Paris (France)
}

(Received January 7, 1988; revised and accepted April 12, 1988)

\begin{abstract}
Johnson, D.A., Schneider, D.A., Nigrini, C.A., Canlet, J.P. and Kent, D.V., 1989. Pliocene-Pleistocene radiolarien events and magnetostratigraphic calibrations for the tropical Indian Ocean. Micropaleontol., 14: 33-64.

A composite of four piston cores from the Central Indian Basin and adjacent Ninetyeast Ridge has yielded a continuous magnetobiostratigraphic reference section for most of the Pliocene and the Pleistocene (0.0-4.5 Ma). We identified thirty-three radiolarian events (first- or last-occurrences), and precisely correlated each event to the Neogene geomagnetic polarity time scale. Thirteen of these events are based on revised taxonomic studies of the genera Anthocyrtidium and Pterocorys. Some events show significant departures from synchroneity: five of the radiolarian first-appearances and seven of the last-appearances are time-transgressive by $0.4 \mathrm{~m} . \mathrm{y}$. or greater. We here propose a revised, eleven-fold radiolarian zonation for the Pliocene-Pleistocene, using zonal boundaries defined by events which are easily recognized and are demonstrably synchronous in the tropical Indo-Pacific. The sequence of faunal and floral events reported in this paper will allow high-resolution biostratigraphic correlations within the tropical Indian Ocean; however, the same sequence of events is not necessarily applicable to other tropical or extratropical regions.
\end{abstract}

\section{Introduction}

The equatorial Pacific has been a classic site for identifying diagnostic biostratigraphic horizons, establishing biozonations for calcareous and siliceous assemblages and constructing a precise calibration of faunal and floral events

${ }^{1}$ Contribution No. 6687 of Woods Hole Oceanographic Inst. ${ }^{2}$ Contribution No. 4434 of Lamont-Doherty Geological Obs. to the globally-synchronous sequence of geomagnetic polarity reversals (e.g. Hays et al., 1969; Gartner, 1973; Johnson and Knoll, 1975; Saito et al., 1975; Burckle, 1977; Theyer et al., 1978; Takayanagi et al., 1979; Barron et al., 1985 ). Utilization of multiple criteria for age control within a given stratigraphic interval may allow quite high precision ( 0.1 to $0.3 \mathrm{~m} . \mathrm{y}$.) for both local and regional correlations (e.g. Berggren et al., 1980, 1985a, 1985b ).

A common presumption in biostratigraphic 
studies of marine sedimentary sequences has been that, whereas lithofacies and acoustic reflectors are commonly time-transgressive (e.g. Haq et al., 1987), by contrast biohorizons and biozonations are essentially synchronous and therefore can be used for regional or even global correlations. Indeed for many faunal and floral events, the presumption of global synchroneity appears to be valid (e.g. Hays and Shackleton, 1976; Thierstein et al., 1977; Morley and Shackleton, 1978; Haq et al., 1980; Backman and Shackleton, 1983). Nevertheless, with increasing refinements in the accuracy and precision of magnetic polarity stratigraphy (Berggren et al., 1985b), it has now become possible to re-examine the degree to which the traditional assumption of biostratigraphic synchroneity is valid, and over what geographic regions one may expect to encounter significant departures from synchroneity (i.e. beyond the analytical and interpolative uncertainties associated with paleomagnetic age correlations ).

In recent years considerable evidence has emerged that not all biostratigraphic components of "global" time scales can be presumed to be synchronous. Significant departures from synchroneity have been noted in cores spanning latitudinal climate gradients in the eastern Pacific (Keller and Barron, 1981) and in the northeastern Atlantic (e.g. Baldauf et al., 1986). Dowsett (1987) has recently applied graphic correlation techniques to assess the extent of latitudinal diachroneity for planktonic microfossils on a more global scale. In addition to latitudinal effects, there is clear evidence of non-synchroneity within a given climatic regime, such as the tropical Indian/Pacific (Johnson and Nigrini, 1985). These departures from synchroneity present significant complications to the task of precise stratigraphic correlation. Nevertheless, at the same time these nonsynchronous events may be quite useful guides to our understanding of patterns of floral and faunal migration and/or evolution.

In view of the growing evidence for diachronous biostratigraphic "datum levels", a primary goal of high-resolution stratigraphic studies should be to re-assess each of the biostratigraphic events which comprise global time scales, and to establish which of the marker horizons are applicable and synchronous over a wide region, and which are demonstrably nonsynchronous. Such a "disentangling" procedure may reduce substantially the number of reliable marker horizons remaining which are demonstrably synchronous. Nevertheless, the consequences of this process will be important in two respects: (1) the exclusion of demonstrably non-synchronous events will allow greater confidence and precision in biostratigraphic correlation; and (2) the discarded, non-synchronous events will be crucial in pointing the way to understanding patterns of plankton migration and species evolution.

In this paper our objective is to propose a high-resolution magneto-biostratigraphic reference section for the tropical Indian Ocean for the Pliocene-Pleistocene (0.0-4.5 Ma), based on radiolarian assemblages. We anticipate that this model will serve as a reference for ODP Indian Ocean drilling in 1987-1989. We further expect that our suggested correlations can eventually be expanded so as to include the calcareous microfossil events and zonations.

Our work in this paper extends the previous efforts of Opdyke and Glass (1969) and Burckle and Opdyke (1977). Here we present detailed faunal studies of four paleomagneticallydated tropical Indian Ocean cores in which we have calibrated 33 radiolarian events, some of which have not been previously described, to the isotopic and paleomagnetic time scales. Our studies lead us to propose a revision in the tropical radiolarian zonation for the Pliocene/ Pleistocene. We suggest discarding the Spongaster lineage as a criterion for defining zonal boundaries due to its demonstrable non-synchroneity and the scarcity of specimens of this genus in Indian Ocean cores. We propose an alternative zonation based upon several Pliocene radiolarian events which are more sharply defined in the Indian Ocean. 


\section{Material studied}

We examined approximately 150 piston cores from the tropical Indian Ocean (10 degrees North to 16 degrees South) which were longer than 8 meters, and prepared smear slides and radiolarian slides from 3 to 5 samples in each core to assess whether pre-Pleistocene sediment was present. Most of the cores were from the collection at Lamont-Doherty Geological Observatory; in addition we sampled several large-diameter piston cores from the Marion Dufresne collection at the Muséum National d'Histoire Naturelle in Paris (Caulet et al., 1984). Within this suite of cores we identified thirty cores of pre-Pleistocene age which contained sufficient siliceous microfossils to allow biostratigraphic confirmation of magnetic polarity determinations. Most of these pre-Pleistocene cores are clustered in the Central Indian Basin, at a depth of $>5000$ meters, between $04^{\circ}$ South and $15^{\circ}$ South (Fig. 1; Table I). Radiolaria and diatoms are common and well preserved in this region; calcareous microfossils are absent, except on the adjacent Ninetyeast Ridge and Chagos-Maldive Ridge. We selected four of these pre-Pleistocene cores as a stratotype (Table I, part A) and carried out detailed biostratigraphic and paleomagnetic analyses of these cores in order to construct a composite type-section for the Pliocene-Pleistocene.

We first sought a siliceous core which had reliable 0-18 age control in the late Pleistocene. Core VM34-53, from the Ninetyeast Ridge, appeared to be the best prospect (Peterson and Prell, 1985). Initial interpretation of the 0-18 profile by Peterson and Prell suggested a basal age of $0.81 \mathrm{Ma}$, or uppermost Matuyama. In this paper we have modified Peterson and Prell's chronology below isotope stage 15 in core VM34-53, based on our determination that the entire core is of Brunhes age.

A second core selected for the composite stratotype is RC14-22 (Burckle and Opdyke, 1977, fig. 3), extending to the uppermost Pliocene, 2.4 Ma. The third core is MD81-369, extending to

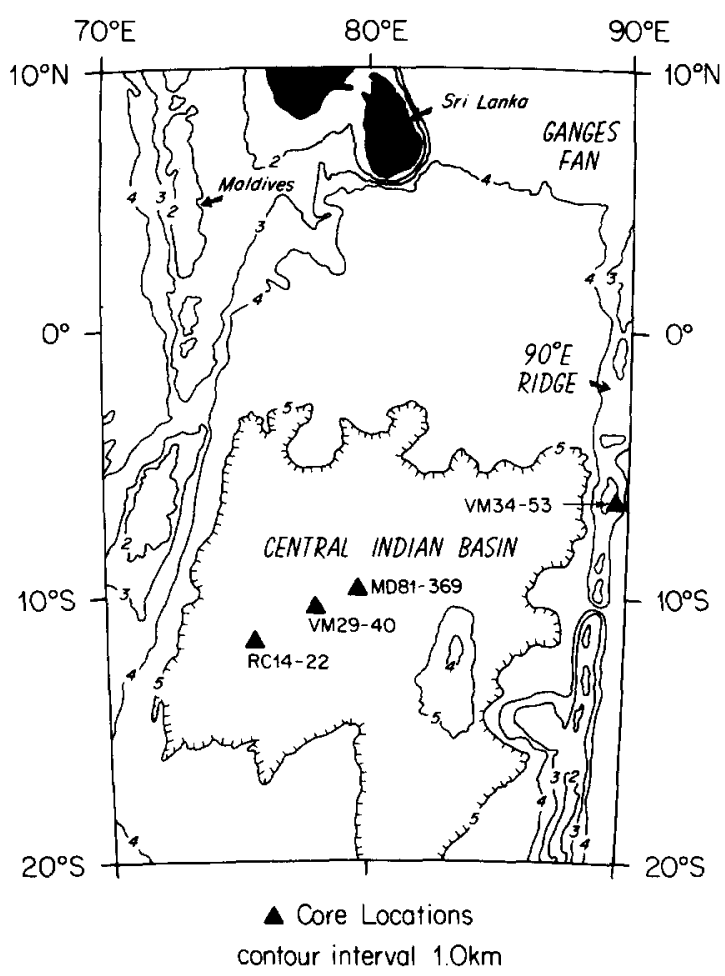

Fig. 1. General bathymetry of Central Indian Basin and part of the Ninetyeast Ridge, after Sclater and Fisher (1974). Triangles mark the locations of the four cores included in this study. Exact core locations are listed in Table I.

the top of the Gilbert " $\mathrm{C}$ " event (Sidufjall) at 4.41 Ma. The fourth core selected, VM29-40, was previously studied by Burckle and Opdyke (1977, fig. 3). We examined samples in this core from the lower Matuyama, Gauss, and upper Gilbert interval, extending from about 2.2 to 4.0 Ma. The geomagnetic polarity time scale of Berggren et al. (1985b) is used.

With this composite set of overlapping cores, we were able to document most of the radiolarian events in at least two cores. The resulting composite stratotype section contains a sequence of thirty-three radiolarian datum levels, which can be compared with the sequence previously established for the tropical Pacific (Theyer et al., 1978; Riedel and Sanfilippo, 1978; Sanfilippo et al., 1985). In this comparison, we have been able to establish that the evolutionary transitions in the Spongaster ber- 


\section{TABLE I}

Locations of Indian Ocean cores examined in this study.

Listing of all cores examined in this study. The four cores in Part A comprise our magneto-biostratigraphic type section. Part B lists additional pre-Pleistocene cores from the Central Indian Basin region with well-preserved biogenic silica. Some of these were secluded from further study due to a noisy paleomagnetic record; intermittent intervals which are barren of silica; evidence for episodes of turbidite redeposition; evidence for coring disturbance; or desiccation and shrinkage of the core during storage. The large number of pre-Pleistocene cores from the region demonstrates the relative continuity of pre-Pleistocene strata over much of the Central Indian Basin.

A. Cores chosen for magneto-biostratigraphic type-section

\begin{tabular}{|c|c|c|c|c|}
\hline Core number & Location $^{\circ}$ & Length & $\begin{array}{l}\text { Depth } \\
\text { (m) }\end{array}$ & $\begin{array}{l}\text { Age range } \\
\text { (m.y.) }\end{array}$ \\
\hline VM34-53 & $\begin{array}{l}06^{\circ} 07^{\prime} \mathrm{S} \\
89^{\circ} 35^{\prime} \mathrm{E}\end{array}$ & $550 \mathrm{~cm}$ & 3812 & $0.0-0.65$ \\
\hline RC14-22 & $\begin{array}{l}11^{\circ} 28^{\prime} \mathrm{S} \\
75^{\circ} 09^{\prime} \mathbf{E}\end{array}$ & $1698 \mathrm{~cm}$ & 5276 & $0.0-2.4$ \\
\hline MD81-369 & $\begin{array}{l}10^{\circ} 03^{\prime} \mathrm{S} \\
79^{\circ} 48^{\prime} \mathrm{E}\end{array}$ & $1772 \mathrm{~cm}$ & 5293 & $0.0-4.4$ \\
\hline VM29-40 & $\begin{array}{l}10^{\circ} 29^{\prime} \mathrm{S} \\
78^{\circ} 03^{\prime} \mathrm{E}\end{array}$ & $1788 \mathrm{~cm}$ & 5325 & $2.5-4.0$ \\
\hline
\end{tabular}

\begin{tabular}{llll}
\hline \multicolumn{3}{l}{ B. Additional pre-Pleistocene siliceous cores examined } \\
\hline Core number & Latitude (S) & Longitude (E) & Basal age ${ }^{1}$ \\
\hline RC12-327 & $01^{\circ} 44^{\prime}$ & $57^{\circ} 50^{\prime}$ & Late Pliocene ${ }^{2}$ \\
RC12-328 & $03^{\circ} 57^{\prime}$ & $60^{\circ} 36^{\prime}$ & Late Pliocene \\
RC14-23 & $09^{\circ} 11^{\prime}$ & $76^{\circ} 45^{\prime}$ & Middle Pliocene \\
RC14-24 & $06^{\circ} 38^{\prime}$ & $79^{\circ} 26^{\prime}$ & Late Pliocene \\
RC14-25 & $06^{\circ} 44^{\prime}$ & $80^{\circ} 49^{\prime}$ & Early Pliocene \\
RC14-26 & $09^{\circ} 08^{\prime}$ & $86^{\circ} 01^{\prime}$ & Late Miocene \\
RC14-32 & $07^{\circ} 26^{\prime}$ & $87^{\circ} 42^{\prime}$ & Late Pliocene \\
VM19-169 & $10^{\circ} 13^{\prime}$ & $81^{\circ} 37^{\prime}$ & Late Miocene \\
VM19-170 & $07^{\circ} 54^{\prime}$ & $81^{\circ} 25^{\prime}$ & Late Miocene $(?)^{3}$ \\
VM19-171 & $07^{\circ} 04^{\prime}$ & $80^{\circ} 46^{\prime}$ & Early Pliocene \\
VM29-34 & $05^{\circ} 21^{\prime}$ & $74^{\circ} 24^{\prime}$ & Early Pliocene \\
VM29-36 & $05^{\circ} 23^{\prime}$ & $76^{\circ} 37^{\prime}$ & Middle Pliocene \\
VM29-39 & $07^{\circ} 42^{\prime}$ & $77^{\circ} 23^{\prime}$ & Middle Pliocene \\
VM29-42 & $13^{\circ} 45^{\prime}$ & $77^{\circ} 39^{\prime}$ & Early Pliocene \\
VM29-43 & $12^{\circ} 20^{\prime}$ & $75^{\circ} 05^{\prime}$ & Early Pliocene ${ }^{4}$ \\
VM29-44 & $10^{\circ} 15^{\prime}$ & $72^{\circ} 23^{\prime}$ & Late Pliocene \\
VM33-54 & $11^{\circ} 01^{\prime}$ & $84^{\circ} 41^{\prime}$ & Late Pliocene \\
VM33-55 & $04^{\circ} 44^{\prime}$ & $81^{\circ} 42^{\prime}$ & Early Pliocene \\
VM34-66 & $04^{\circ} 27^{\prime}$ & $60^{\circ} 42^{\prime}$ & Late Pliocene \\
MD77-157 & $04^{\circ} 48^{\prime}$ & $90^{\circ} 02^{\prime}$ & Middle Miocene \\
MD81-364 & $12^{\circ} 33^{\prime}$ & $83^{\circ} 36^{\prime}$ & Late Pliocene \\
MD81-367 & $06^{\circ} 59^{\prime}$ & $80^{\circ} 06^{\prime}$ & Early Pliocene \\
MD81-368 & $09^{\circ} 58^{\prime}$ & $79^{\circ} 26^{\prime}$ & Late Pliocene \\
MD81-371 & $12^{\circ} 02^{\prime}$ & $79^{\circ} 04^{\prime}$ & Late Pliocene \\
MD81-374 & $12^{\circ} 48^{\prime}$ & $77^{\circ} 43^{\prime}$ & Middle Pliocene \\
MD81-375 & $12^{\circ} 47^{\prime}$ & $77^{\circ} 46^{\prime}$ & Early Pliocene \\
\hline
\end{tabular}

Age determinations based on examination of 3 or more smear slides and radiolarian samples per core.

${ }^{2}$ Magnetics in Opdyke, 1972, fig. 20.

${ }^{3}$ Magnetics in Burckle and Opdyke, 1977, fig. 9.

${ }^{4}$ Paleomagnetic results in Schneider and Kent (1989).

${ }^{5}$ Biostratigraphy in Caulet, 1978, pp. 579-580. No paleomagnetics available. minghami to $S$. tetras lineage are notably diachronous. As a result we are proposing a new set of criteria for zonal boundaries in the Pliocene, based on our assessment of the degree of non-synchroneity of each datum level.

\section{Physiography and sediment lithology}

The Central Indian Basin is underlain by oceanic crust of early Tertiary to late Cretaceous age, progressing in age northward from ca. $50 \mathrm{Ma}$ at $20^{\circ}$ South to $>75 \mathrm{Ma}$ at the equator (Sclater and Fisher, 1974, fig. 2). Physiographically the basin is bounded on the east by the aseismic Ninetyeast Ridge, on the west by the volcanic atoll lineament of the ChagosMaldive-Laccadive system, and on the south by the Central Indian Ridge (Fig. 1). Even though the basin itself is aseismic, significant intraplate compressional deformation of the oceanic crust and overlying sediments has been observed (Weissel et al., 1980).

Most of the basin floor lies below a depth of 4500 meters (Fig. 1), which approximates the carbonate compensation depth in this region (Kolla et al., 1976; Peterson and Prell, 1985a). Consequently, sedimentation on the basin floor is comprised principally of terrigenous, hemipelagic and biogenic siliceous components, with interspersed intervals of volcanogenic material (Davies and Kidd, 1977). The distal Ganges Fan enters the Central Indian Basin from the northeast, and thus fine-grained terrigenous components are of increasing abundance toward the northern margins of the Basin. By and large, however, the sediments on the Basin floor are relatively devoid of coarse-grained calcareous and terrigenous components, thereby allowing long piston cores to be readily obtained throughout much of the basin floor.

It is clear that biogenic silica sedimentation in the Central Indian Basin varies substantially in space and in time. Maps of biogenic silica production (Lisitzin, 1967, 1972) and of radiolarian species diversity and abundance (Petrushevskaya, 1973; Johnson and Nigrini, 
$1980,1982)$ indicate that modern siliceous sedimentation is confined to the northern part of the Basin, north of approximately 12 degrees South. Preliminary down-core studies (e.g. Caulet, $1977 ; 1978$ ) indicate that temporal variations in silica flux during the late Neogene may be significant at a given locality. Such variations may indicate changes in the intensity of the equatorial current system in response to variations in the strength of the monsoonal circulation, and variations in the position of the hydrochemical "front" (Wyrtki, 1973) in response to fluctuations in the westward throughflow of low-latitude Pacific water (Piola and Gordon, 1984).

\section{Paleomagnetic stratigraphy}

Previous investigations of the paleomagnetism of deep-sea sediment cores from the tropical Indian Ocean were undertaken by Opdyke and Glass (1969), Opdyke (1972) and Burckle and Opdyke (1977). For the most part, the tropical Indian Ocean cores examined during these earlier studies were found to contain Pleistocene age sediments. Those cores which included substantial pre-Pleistocene intervals were often marred by the presence of gaps in the sedimentary record. Two cores (RC14-22 and VM29-40) studied by Burckle and Opdyke (1977) do, however, provide good pre-Pleistocene records and are used along with two newly studied cores (VM34-53 and MD81-369) to construct the composite "type-section". A composite of the four cores produces an essentially complete paleomagnetic record from the tropical Indian Ocean, spanning most of the Plio-Pleistocene (0.0-4.5 Ma).

\section{Methods}

The experimental procedure used here to determine the magnetostratigraphy of the two newly-studied cores follows that established during many prior studies (e.g. Opdyke, 1972). We took samples of $6 \mathrm{cc}$ at intervals of 5 to 20 cm from what appeared to be the least physically-disturbed intervals of the cores. A representative subset of these samples was subjected to progressive alternating field (AF) demagnetization. From the demagnetization results we then determined an optimum AF level (one above which the magnetization showed only one component) to use in the blanket treatment of the remaining samples from the core.

Because no orienting device was used when these piston cores were originally taken, absolute magnetic declination could not be ascertained. However, the presence of $180^{\circ}$ shifts in declination (within physically continuous sections of core ) can help identify reversals which would be less clearly defined if only inclination measurements were utilized. Some caution must be exercised in this approach because apparent declination shifts may occur at the breaks between core sections. Such spurious shifts result when opposite halves of the split core are confused during handling. Attempts were made to avoid such uncertainty for the cores in the Lamont-Doherty collection; however, no procedure was used to maintain the relative orientation of successive core sections for the Marion Dufresne cores.

\section{Results}

\section{Core VM34-53}

This core shows inclinations of $-10^{\circ}$ to $-20^{\circ}$ throughout its length. Two points near the base of the core, however, show aberrant declination values (Fig. 2). As the inclination of these points is consistent with the rest of the core, we presume that the anomalous declinations are caused by twisting of the core during its handling. The negative inclinations found throughout the core (site latitude $6^{\circ}$ South) would indicate that all of the core is of normal polarity. Previous biostratigraphic and oxygen isotopic analyses of core VM34-53 (Peterson and Prell, 1985b, fig. 3 ) have shown this core to be Late Pleistocene, with an inferred basal age of 0.81 Ma (Peterson and Prell, 1985b, table 3). 
Our paleomagnetic observations, however, suggest that these sediments were deposited entirely within the Brunhes chron, and thus we require some modification to Peterson and Prell's (1985b, table 3 ) isotope-based age model below isotope stage 15 . We assign the $0-18 \mathrm{~min}$ imum at $435 \mathrm{~cm}$ to stage 15 ; the $0-18$ maximum at $465 \mathrm{~cm}$ to stage 16 ; the $0-18$ minimum at 515 $\mathrm{cm}$ to stage 17 ; and the $0-18$ maximum at 535 $\mathrm{cm}$ to stage 18. Our revised chronology for VM34-53 is shown in Fig. 2, and is reflected in the estimated ages of radiolarian samples from this core (Table II).

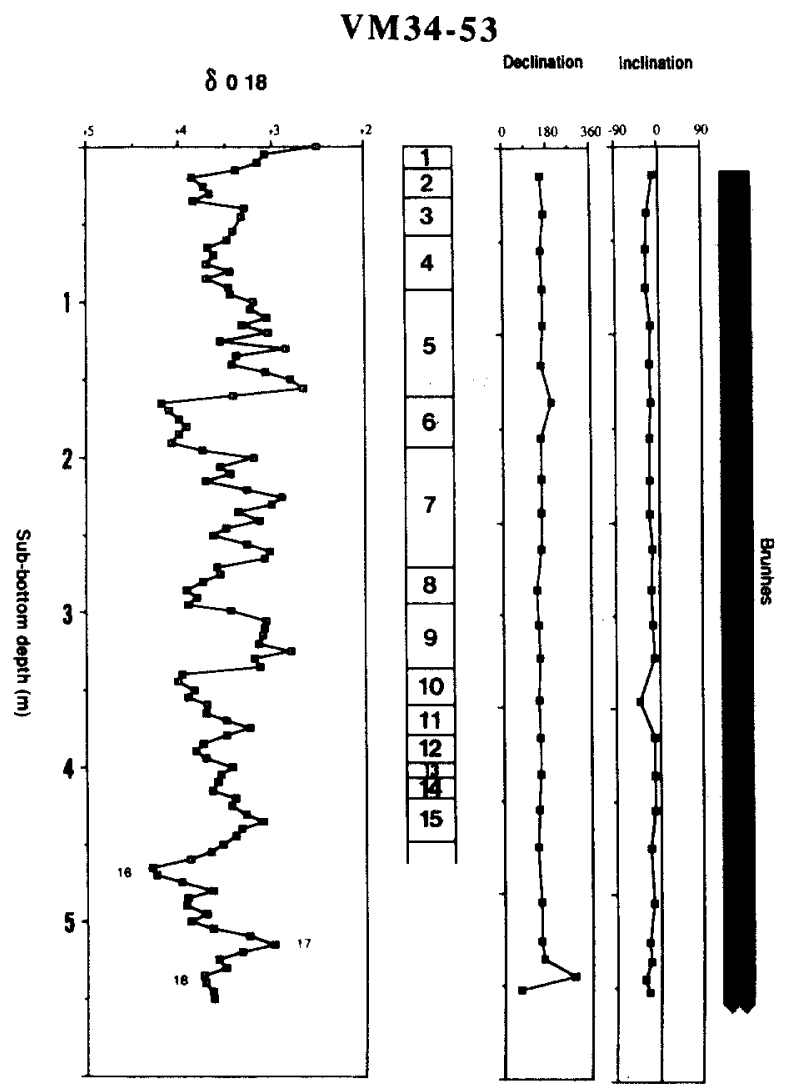

Fig. 2. Paleomagnetic inclination, declination and magnetic polarity logs for Core VM34-53, together with the oxygen isotopic analyses and stage designations of Peterson and Prell (1985b). The identification of isotope stages below stage 15 has been revised from that of Peterson and Prell, so as to be consistent with the paleomagnetic observations reported in this paper.

\section{Core $R C 14-22$}

This core was previously examined by Burckle and Opdyke (1977, fig. 3), and was found to contain sediments of Brunhes and Matuyama age down to approximately $2.4 \mathrm{Ma}$. Although the overall sedimentation rate is high $(7 \mathrm{~m} /$ m.y.) and the quality of the paleomagnetic data generally is good, the inclination record appears incomplete, because the Jaramillo subchronozone is poorly represented (Fig. 4). The Jaramillo is, however, well developed in the declination record, despite the presence of several spurious declination shifts. For example, the 180-degree shifts at 1125 and $1160 \mathrm{~cm}$ (Fig. 4) do not indicate polarity reversals. Rather, they occur at physical breaks bounding an interval which appears to have been accidentally misoriented (the working half of the core being stored in the archive position, and vice versa ).

The identification of the Jaramillo subchronozone (0.91-0.98 Ma) between 796 and $828 \mathrm{~cm}$ is consistent with the presence of the Anthocyrtidium angulare LAD just below it at $870 \mathrm{~cm}$ (Table III). This distinct faunal event

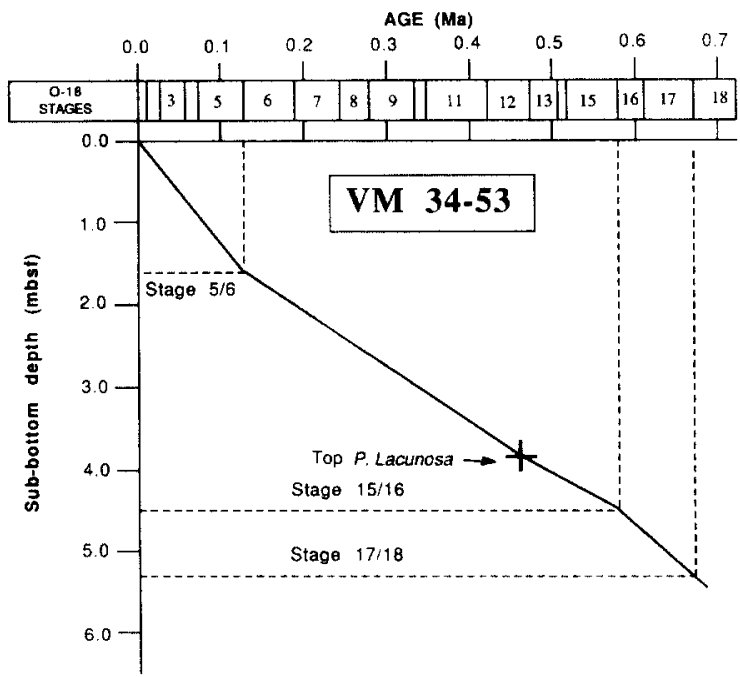

Fig. 3. Age-depth plot for core VM34-53, using the Stage 5/ 6 boundary and the $P$. lacunosa datum of Peterson and Prell (1985b). Using our revised interpretation of isotope stages below stage 15 , the basal age of the core (at $550 \mathrm{~cm}$ ) is approximately $0.68 \mathrm{Ma}$. Isotope chronology of stages 15 through 18 follows Morley and Hays (1981, Table 4). 


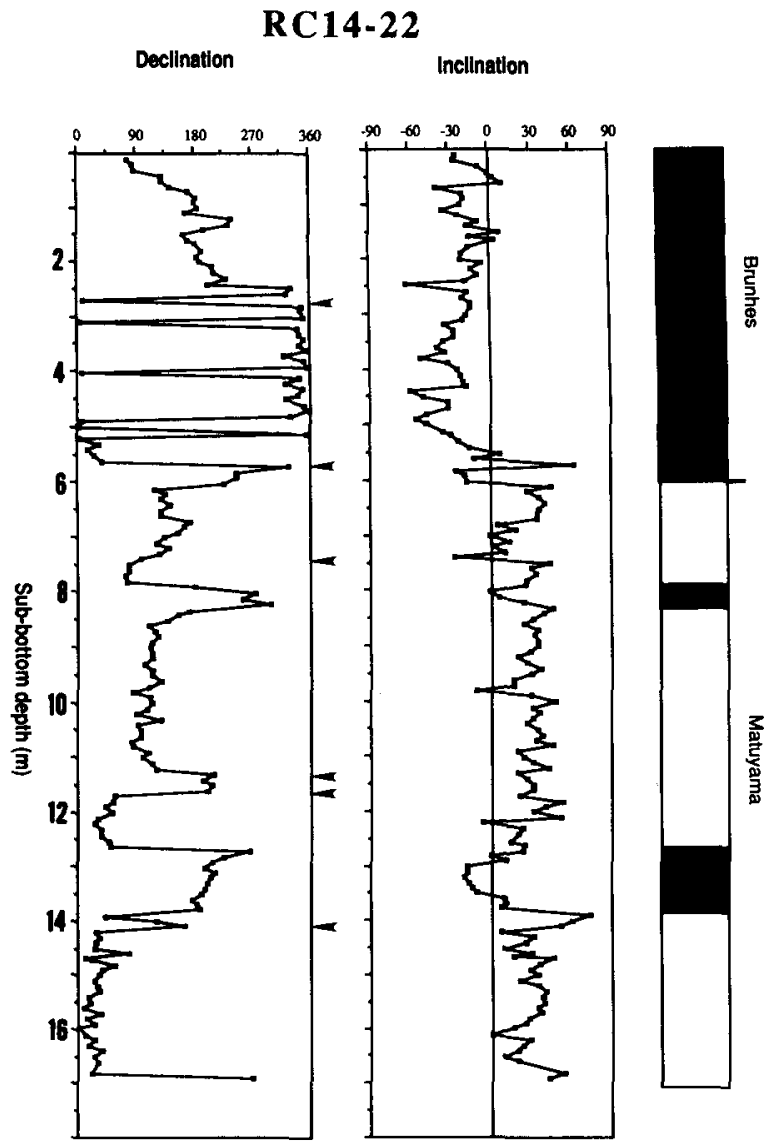

Fig. 4. Inclination, declination, and magnetic polarity logs for Core RC14-22, after $15 \mathrm{mT}$ demagnetization (based on paleomagnetic data of Burckle and Opdyke, 1977). Arrows on declination $\log$ indicate position of physical breaks where misorientation may cause spurious declination shifts.

is of nominal age 1.0 Ma (Johnson and Knoll, 1975; Johnson and Nigrini, 1985). Furthermore, Burckle and Opdyke's (1977) original identification of the Olduvai subchronozone (1.66-1.88 Ma) between 1265 and $1385 \mathrm{~cm}$ appears well supported by the occurrence of the Pterocanium prismatium LAD at $1190 \mathrm{~cm}(\mathrm{Ta}-$ ble III). This distinct faunal marker near the Pliocene-Pleistocene boundary is of nominal age 1.55-1.6 Ma (Hays et al., 1969; Johnson and Knoll, 1975; Johnson and Nigrini, 1985).

\section{Core $M D 81-369$}

This core (Fig. 5) presents a somewhat complicated magnetostratigraphy. Because this core was stored in 12 sections ( $1.5 \mathrm{~m}$ each) which were not oriented relative to each other, the declination record contains many spurious shifts at the breaks between core sections. Consequently, only those declination shifts which are also accompanied by distinct reversals in inclination are considered reliable indications of polarity reversals. Fortunately, changes in inclination from this site (at 10 degrees South) provide a clear record of magnetic polarity reversals. Negative inclinations indicate normal polarity, and positive inclinations designate reversed polarity.

Biostratigraphic analyses of Core MD81-369 support the interpretation of magnetostratigraphy shown in Fig. 5. For example, the Pterocanium prismatium LAD occurs at $465 \mathrm{~cm}$ (Table IV), just above what we identify as the

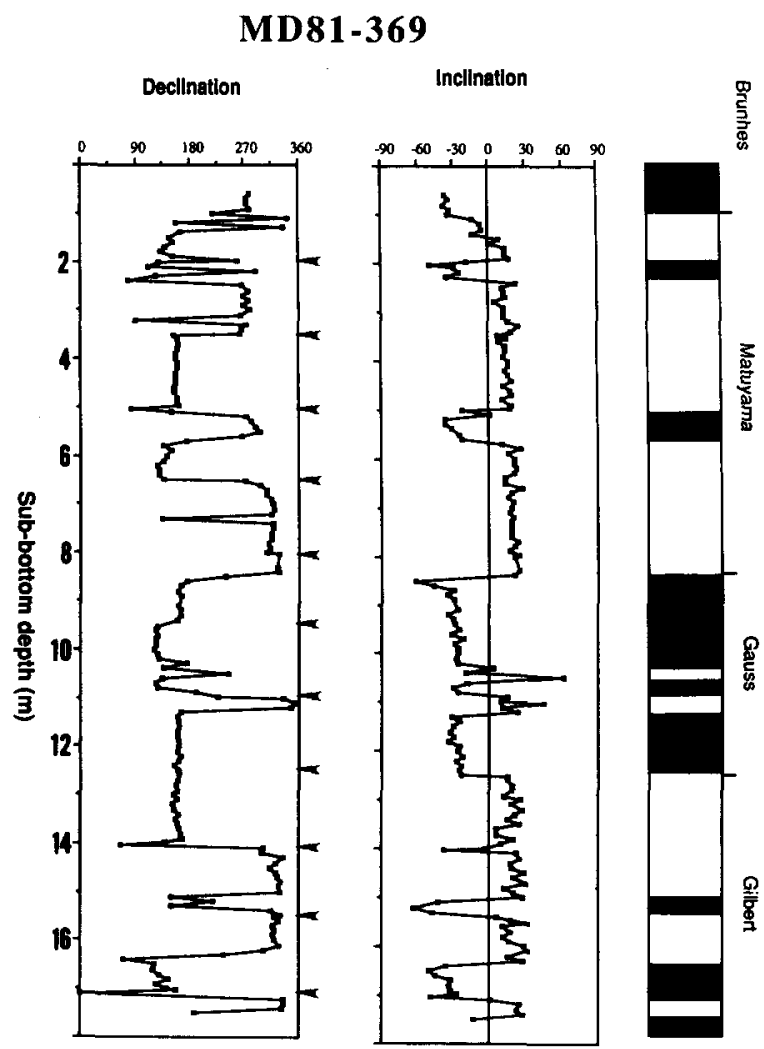

Fig. 5. Inclination, declination, and magnetic polarity logs for core MD81-369 after $20 \mathrm{mT}$ demagnetization. Arrows indicate breaks between core sections, as in Fig. 4 . 
Olduvai subchronozone. Although the Brunhes interval appears anomalously short, the record of older magnetic chrons seems largely complete, with even the shorter subchronozones present (e.g. the Kaena and Mammoth reversed polarity zones within the Gauss). Thus it appears that core MD81-369 spans over 4.4 million years, although the interpretation of the chronology within the lowermost (Gilbert) interval of the core remains somewhat problematic. The single sample with negative inclination at $1400 \mathrm{~cm}$ may indicate the presence of a short normal polarity zone, or it may simply reflect some physical disturbance of the core. We favor the latter interpretation, because the position of this sample (at the break between two core sections) is one which is often prone to physical disturbance. Consequently we interpret the two well-developed normal polarity zones in this section (1505-1539 cm and $1635-$ $1712 \mathrm{~cm}$ ) to represent the two youngest normal polarity subchrons (Cochiti and Nunivak) of the Gilbert chron.

The single normal polarity sample at the bottom of the core (Fig. 5) may either be another example of a single spurious point, or it may indicate that the core actually extends to material of normal polarity, presumably the Sidufjall subchronozone. Here again the biostratigraphic control may be helpful. The first appearance of Spongaster pentas occurs at 1704$1710 \mathrm{~cm}$ in this core (Table IV), and has been dated at 4.2-4.3 Ma in the tropical Indian Ocean (Johnson and Nigrini, 1985). On this basis we can confidently assign the normal polarity subchron at $1635-1712 \mathrm{~cm}$ to the Nunivak (4.10$4.24 \mathrm{Ma}$ ). Extrapolation of the mean sedimentation rate for the pre-Brunhes in this core (about $4.5 \mathrm{~m} / \mathrm{m} . \mathrm{y}$.) would suggest that the top of the Sidufjall (4.40 Ma) was indeed reached at the base of the core $(1772 \mathrm{~cm}$ depth $)$.

\section{Core VM29-40}

This core was studied previously by Burckle and Opdyke (1977); the paleomagnetic log and

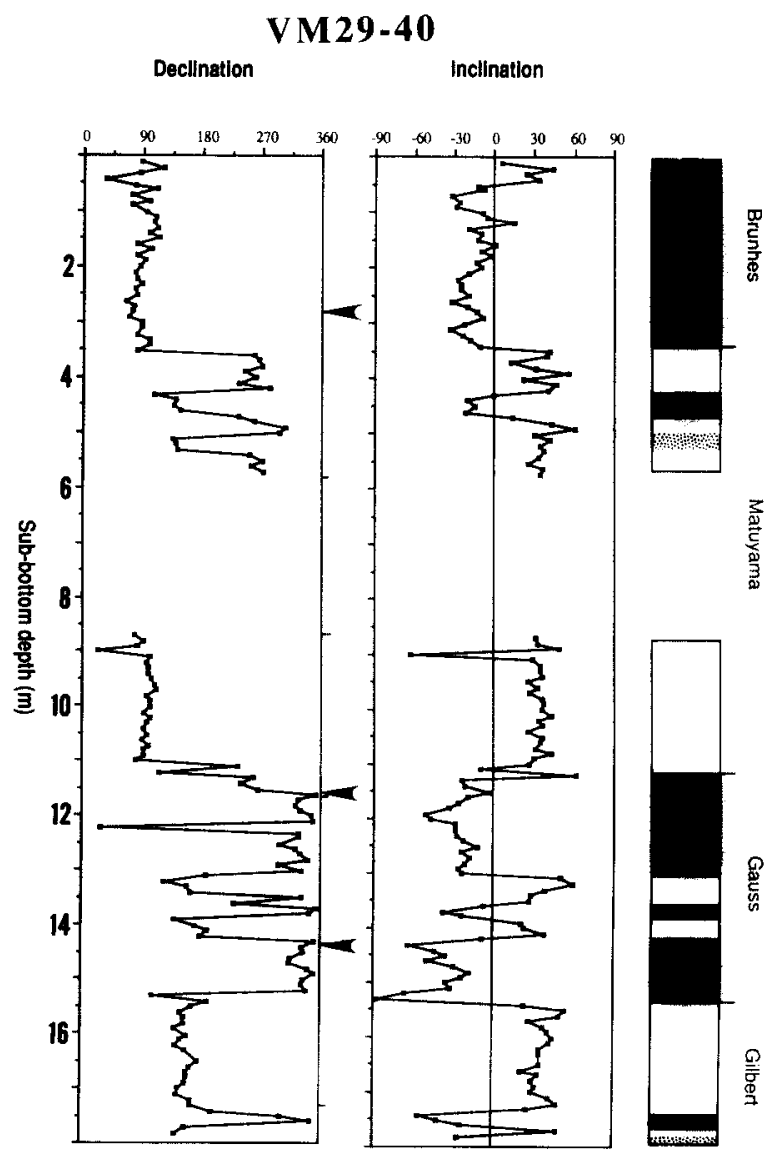

Fig. 6. Inclination, declination and magnetic polarity logs for Core VM29-40 after $15 \mathrm{mT}$ demagnetization (from paleomagnetic data of Burckle and Opdyke, 1977). Convention as in Fig. 4.

polarity interpretation are shown in Fig. 6. The interpretation differs from that shown in Burckle and Opdyke's (1977) fig. 3 in that a drafting error has been corrected. Also, over two short intervals the polarity interpretation has been left undetermined. The lower undetermined interval occurs at the very bottom where the core may have been physically disturbed. The upper undetermined interval occurs just below the Jaramillo subchronozone. This too may reflect some disturbance, or perhaps it may record the short Cobb Mountain normal polarity subchron (Mankinen et al., 1978), evidence of which has also been found in other deep sea sediments (Clement and Kent, 1987). 


\section{Assessment of Paleomagnetic results}

Age-depth curves, based on the time scale of Berggren et al. (1985a, 1985b), help to assess the completeness of the stratigraphic record in the cores comprising our composite reference section (Figs. 3 and 7). The paleomagnetic data on core VM34-53 give a lower limit of $7.5 \mathrm{~m} /$ m.y. on the overall sedimentation rate. The revised isotope stratigraphy (Fig. 2), however, suggests that the sedimentation rate is somewhat variable (Fig. 3 ), being higher near the top of the core (about $13 \mathrm{~m} / \mathrm{m} . \mathrm{y}$.) than near the bottom (about $7 \mathrm{~m} / \mathrm{m} . y$.).

Core RC14-22 shows largely uniform sedimentation at an average rate of $7.2 \mathrm{~m} / \mathrm{m}$.y. The age-depth relationship for MD81-369 indicates some variation over short intervals, but the average rate below the Brunhes/Matuyama boundary is $4.5 \mathrm{~m} / \mathrm{m} . y$., which is essentially equal to that of Core VM29-40. The Brunhes interval of Core MD81-369 is anomalously short, indicating either a recent period of erosion or reduced sedimentation, or perhaps an incomplete recovery of the uppermost portion of the sediment column.

\section{Radiolarian biostratigraphy}

\section{Selection and identification of events}

We (DJ, JPC and CN) first compiled a listing of late Neogene morphotypic radiolarian events (i.e., first- and last-appearance datum levels) based on presence-absence data. Our selection of events drew upon previous studies of Nigrini (1971), Knoll and Johnson (1975), Riedel and Sanfilippo (1978), Caulet (1982, 1986), Johnson and Nigrini (1985), Sanfilippo et al. (1985), Nigrini and Caulet (1988) and Caulet and Nigrini (1988). We agreed upon a standard taxonomic concept for each species included (see Appendix), in order to insure the application of consistent criteria for ascertaining the stratigraphic ranges of each taxon.

Four cores were chosen for detailed study
(Table I) and sampled at closely-spaced intervals (see Tables II-V). At least three strewn slides were prepared for radiolarians in each sample, using standard preparation procedures (Sanfilippo et al., 1985). Primary responsibility for faunal analysis was divided between us as follows: VM34-53 (DJ), MD81-369 (JPC), RC14-22 and VM29-40 (CN).However, each of us also examined slides from the remaining cores in order to spot check each other's tabulations of species occurrences. Initially we worked independently, and then compared our tabulations of events. We found surprisingly few discrepancies, and those which did occur could be resolved with relative ease. Raw census data are tabulated in the following way (Tables II through $\mathrm{V}$ ): $\mathrm{P}=$ present; $+=$ single specimen; $-=$ searched for, but not found; ?=dubious identification.

A synthesis of our determinations of biostratigraphic datum levels is presented in Table VI, showing the depths (in $\mathrm{cm}$ ) and the corresponding ages $(\mathrm{Ma})$ between which each event occurs. Table VI also includes similar, though less precise, observations from DSDP Sites 214, 586, and 573 (Johnson and Nigrini, 1985). One limitation of the Johnson and Nigrini (1985) study was that the authors had data available from only a single Indian Ocean drill site, and they relied primarily upon indirectly derived paleomagnetic age control. In this paper we present paleomagnetically-calibrated datum levels for the tropical Indian Ocean, thereby allowing a more precise comparison with the tropical Pacific sequence (Sanfilippo et al., 1985 ), and a more precise assessment of possible non-synchronous events.

We note that there is close agreement between the ages of events derived from paleomagnetically-dated cores and those ages estimated by Johnson and Nigrini (1985) for DSDP Site 214 nearby (Table VI). This agreement suggests that the first-order patterns of Indian/Pacific diachroneity suggested by Johnson and Nigrini (1985) are indeed valid, although considerable fine-tuning of the ages of 
events will be required in order to document the degree of diachroneity more precisely.

In the following listing of radiolarian events we assess the reliability and possible diachroneity of each. All radiolarian events are tabulated in Table VI and those which are considered non-synchronous by $0.4 \mathrm{~m} . \mathrm{y}$. or greater are listed in Table VII. We also list several radiolarian events which were initially tabulated, but were later excluded due to problems in taxonomy, species abundance, or sharpness of the event.

\section{Radiolarian events}

Base Buccinosphaera invaginata. Evolves from Collosphaera orthoconus (Knoll and Johnson, 1975; Bjorklund and Goll, 1979) at around 0.17 $\mathrm{Ma}$, near the isotope stage 6/7 transition. Previously selected as a zonal boundary (Nigrini, 1971). Requires well-preserved assemblages and reliable core-top recovery in order to recognize event; drill cores may not be adequate. Probably synchronous, based on published Pacific Ocean data and Knoll and Johnson (1975).

Top Stylatractus universus. Globally synchronous event at $0.42 \mathrm{Ma}$ (Morley and Shackleton, 1978). Reliable and easily recognized event; species may be confused with a similar but smaller (unidentified) form. Here selected as a zonal boundary marker.

Base Collosphaera tuberosa. Distinctive morphology, though can sometimes be confused with $C$. orthoconus. Previously selected as a zonal boundary marker (Nigrini, 1971). Probably synchronous.

Top Anthocyrtidium nosicaae. An easily recognized and reliable event within tropical Indian Ocean. Diachronous; approx. 0.4 m.y. younger in Indian Ocean than in Pacific.

Top Pterocorys campanula. Evolves to P. hertwigii. Can usually be distinguished from $P$. hertwigii on specimens where abdomen is relatively complete (Caulet and Nigrini, 1988). Synchronous.

Base Pterocorys hertwigii. Evolves from $P$. campanula (Caulet and Nigrini, 1988). Synchronous.

Base Anthocyrtidium euryclathrum. Present only in the Indian Ocean; an easily recognized and reliable event (Nigrini and Caulet, 1988). Top Anthocyrtidium angulare. Easily recognized form, more common in Pacific than in Indian Ocean. Previously selected as a zonal boundary marker (Nigrini, 1971). Synchronous, near the base of Jaramillo.

Base Lamprocyrtis nigriniae. Distinctive, but relatively rare in some areas due to its apparently restrictive geographic range (Johnson and Nigrini, 1980). A short stratigraphic gap is present between this event and the last occurrence of its described ancestor, $L$. neoheteroporos. Synchronous in our tropical samples.

Top Lamprocyrtis neoheteroporos. Probably evolves into $L$. nigriniae. Relatively rare in tropical assemblages. Synchronous.

Top Anthocyrtidium michelinae. Taxon very distinct, more common in Indian Ocean than in Pacific. Extinction is reliable and easily recognized. Synchronous.

Top Pterocanium prismatium. Sharp, reliable, and easily recognized event. Previously selected as zonal boundary marker (Riedel and Sanfilippo, 1971; Sanfilippo et al., 1985). Synchronous, corresponding approximately with the top of the Olduvai and the Pliocene-Pleistocene boundary (Hays et al., 1969; Berggren et al., 1980).

Base Anthocyrtidium angulare. Reliable and easily recognized event. More common in $\mathrm{Pa}$ cific than in Indian Ocean. Synchronous, near the top of the Olduvai.

Base Pterocorys zancleus. Form is rather rare in tropical sediments, and may be confused near the lower end of its range with $P$. campanula. Apparently diachronous, appearing approx. 0.4 m.y. earlier in the Pacific than in Indian Ocean. Top Theocorythium vetulum. Form evolves to T. trachelium, and is easily distinguished from it. Rather rare in Indian Ocean, more common in Pacific. Previously established as diachronous by approx. 0.4 m.y. (Baker, 1983). 


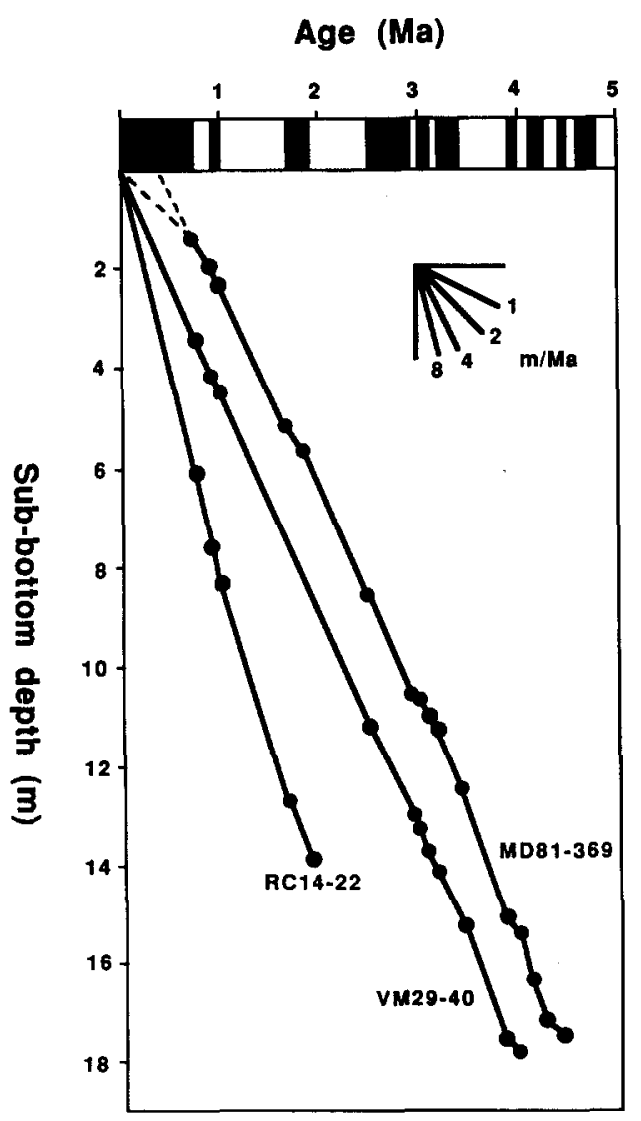

Fig. 7. Age-depth relationships for three of the cores comprising the stratigraphic type section, based on the identification of polarity reversal boundaries and the geomagnetic polarity time scale of Berggren et al. (1985a).

Top Anthocyrtidium jenghisi. Synchronous. Here selected as a zonal boundary marker for the late Pliocene at approx. 2.35 Ma. A smaller variety of this species, which can be confused with $A$. angulare, occurs at the upper and lower limits of its range (Nigrini and Caulet, 1988).

Base Theocalyptra davisiana. Easily recognized and reliable event. Important to distinguish the nominated subspecies from related subspecies (Petrushevskaya, 1967). Synchronous.

Base Lamprocyrtis neoheteroporos. Apparently diachronous by approx. $0.5 \mathrm{~m}$.y. (younger in the tropical Indian Ocean than the tropical $\mathrm{Pa}$ cific). In some tropical locations may be too rare to be a reliable event. In the tropical Indian
Ocean we have not observed its transition from its presumed ancestor, $L$. heteroporos.

Base Theocorythium trachelium. Diachronous by approx. 1 m.y. (older in the tropical Indian Ocean than the tropical Pacific). Event is not especially reliable because a similar, smaller and possibly conspecific form can be found below the FAD of typical $T$. trachelium specimens. There is a stratigraphic gap between the FAD of $T$. trachelium and the LAD of the smaller form.

Top Stichorocys peregrina. Sharp, easily recognized event. Previously selected as a zonal boundary marker (Riedel and Sanfilippo, 1970). Synchronous at 2.65 Ma, near the top of the Gauss.

Top Anthocyrtidium ehrenbergi. A reasonably good event which is more easily recognized in the Pacific than in the Indian Ocean. Diachronous by approx. $0.9 \mathrm{~m} . \mathrm{y}$. (younger in the tropical Indian Ocean than the tropical Pacific).

Top Anthocyrtidium pliocenica. Easily recognizable event. Species is more abundant and more robust in the Pacific than in the Indian Ocean. Diachronous by approx. 1 m.y. (older in the tropical Indian Ocean than the tropical Pacific).

Top Phormostichoartus fistula. Reliable and easily recognized event. Distinguishable from $P$. pitomorphus (Caulet, 1986) by its greater size. Synchronous, at ca. 3.26 Ma. Here selected as a zonal boundary marker for the Pliocene.

Top Lychnodictyum audax. Not a sharp event because there are sporadic occurrences above the last consistent occurrence. Species is easily recognizable, but very rare in the central tropical Pacific (DSDP Site 573). Probably synchronous.

Top Phormostichoartus doliolum. Reliable and easily recognized event. Synchronous, at ca. 3.55 Ma. Here selected as a zonal boundary event for the Pliocene.

Base Amphirhopalum ypsilon. Rare at the lower end of its range, but easily recognizable, even from fragmentary specimens. Synchronous. 
Top Spongaster pentas. Rare in the Indian Ocean. Diachronous by approx. 0.8 m.y.; older in the tropical Indian Ocean than the tropical Pacific.

Base Spongaster tetras. Reliable and easily recognized event. Synchronous.

Top Spongodiscus klingi. Apparently synchronous, but generally too rare to be a useful stratigraphic event.

Top Spongaster berminghami. Very rare in the Indian Ocean. Apparently diachronous by approx. $0.8 \mathrm{~m} . \mathrm{y}$. (younger in the tropical Indian Ocean than in the tropical Pacific).

Top Anthocyrtidium prolatum. Evolves to $A$. zanguebaricum (Nigrini and Caulet, 1988). Synchronous, and here tentatively selected as a zonal boundary marker for the early Pliocene of the Indian Ocean. We have not observed this species in DSDP Site 573 material from the central Pacific, but this may be due to the method of preparation of our Site 573 material. Base Spongaster pentas. Rare in the Indian Ocean. Apparently diachronous by approx. 0.8 m.y. (younger in the tropical Indian Ocean than in the tropical Pacific).

Base Anthocyrtidium ophirense. Probably diachronous by up to $1 \mathrm{~m} . \mathrm{y}$. (younger in the tropical Indian Ocean than the tropical $\mathrm{Pa}$ cific). Occurs near the lower stratigraphic limit of our studied cores (Table VI) and thus may be modified with subsequent observations.

The following events were initially tabulated and evaluated, but later rejected as useful marker horizons:

Top Acrosphaera spinosa hamospina. Too rare.

Base Collosphaera orthoconus. Not a sharp event, and sometimes difficult to distinguish from C. tuberosa.

Base Pterocorys sabae. Not a sharp event. Specimens are small and often broken at the lower end of its range.

Base Anthocyrtidium zanguebaricum. Species is difficult to identify at the lower end of its range, particularly in the Pacific Ocean.
Proposed radiolarian zonation for the PlioPleistocene of the tropical Indian Ocean

We are proposing herein a revised radiolarian zonation for the tropical Indian Ocean (see Fig. 8). Except for Zone NR 11 (Anthocyrtidium prolatum Zone) we believe that this zonation is also applicable to the tropical Pacific Ocean. We have discarded the Spongaster lineage as a zonal boundary criteria, both because of its diachronous nature (Table VII) and because of the scarcity of $S$. pentas and $S$. berminghami in the tropical Indian Ocean.

Our chosen zonal boundaries are based only upon demonstrably synchronous morphotypic events (i.e., first- and last-appearance datum levels, and not on evolutionary transitions). Following the definition of each zone is a stratigraphically ordered list of radiolarian events which occur within the zone in the Indian Ocean. We have noted those events which are diachronous between our Indian and Pacific Ocean sites, and which may not, therefore, occur globally within the same biozone. The first and last appearances, of a taxon are indicated by "Bm" (earliest morphotypic occurrence) and "Tm" (latest morphotypic occurrence). Zonal concepts are those of the International Stratigraphic Guide (Hedberg, 1976).

(Nr. 1) Buccinosphaera invaginata Range Chronozone (Nigrini, 1971; Caulet, 1979)

Defined by the range of Buccinosphaera invaginata, approx. $0.17 \mathrm{Ma}$ to present.

(Nr. 2) Collosphaera tuberosa IntervalChronozone [Nigrini, 1971 (partim.); Caulet, 1979]

Morphotypic top of Stylatractus universus (0.42 $\mathrm{Ma}$ ) to morphotypic bottom of Buccinosphaera invaginata (approx. 0.17 Ma).

(Nr. 3) Stylatractus universus IntervalChronozone [Nigrini, 1971 (partim.); Caulet, 1979] 

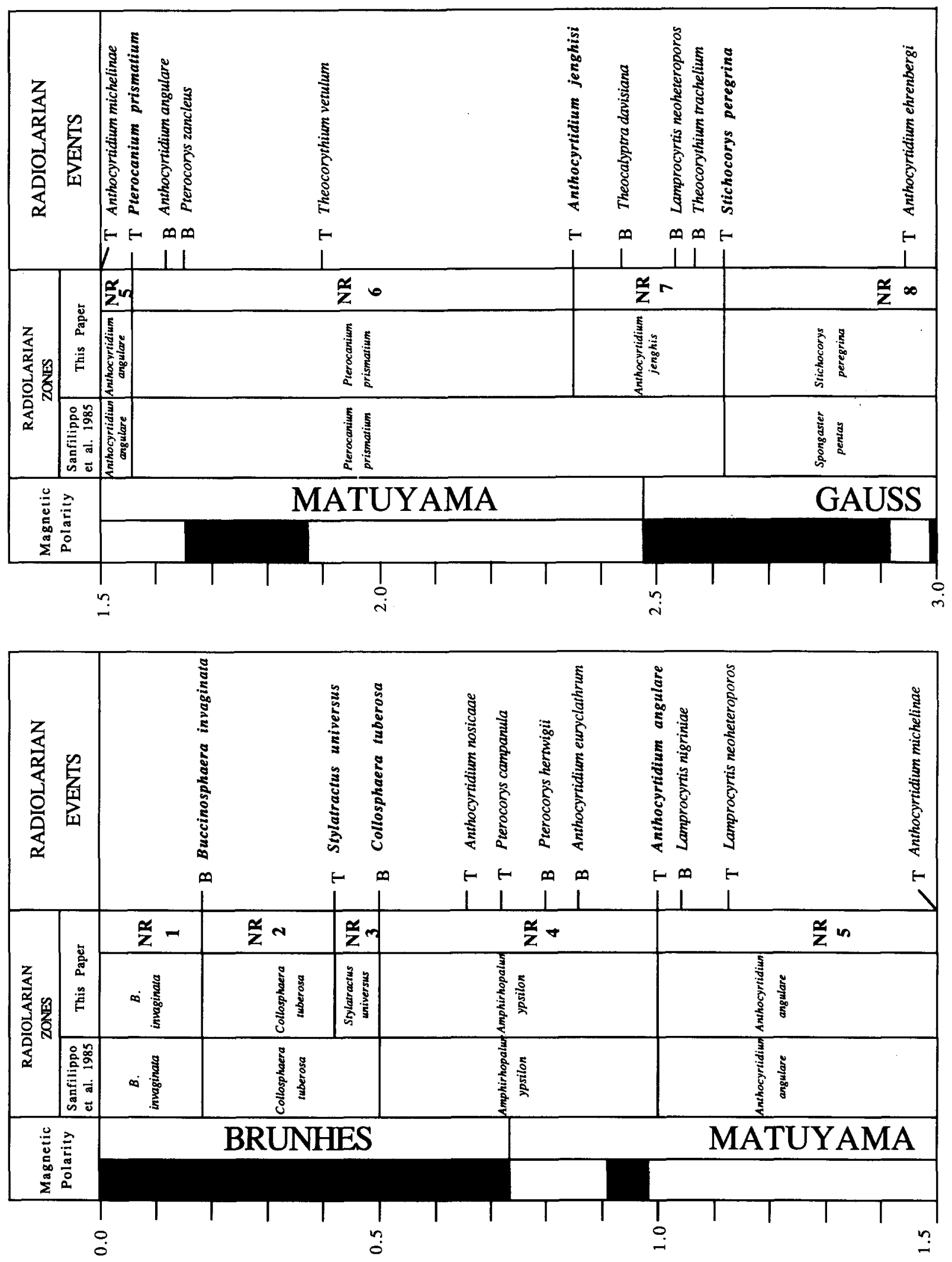


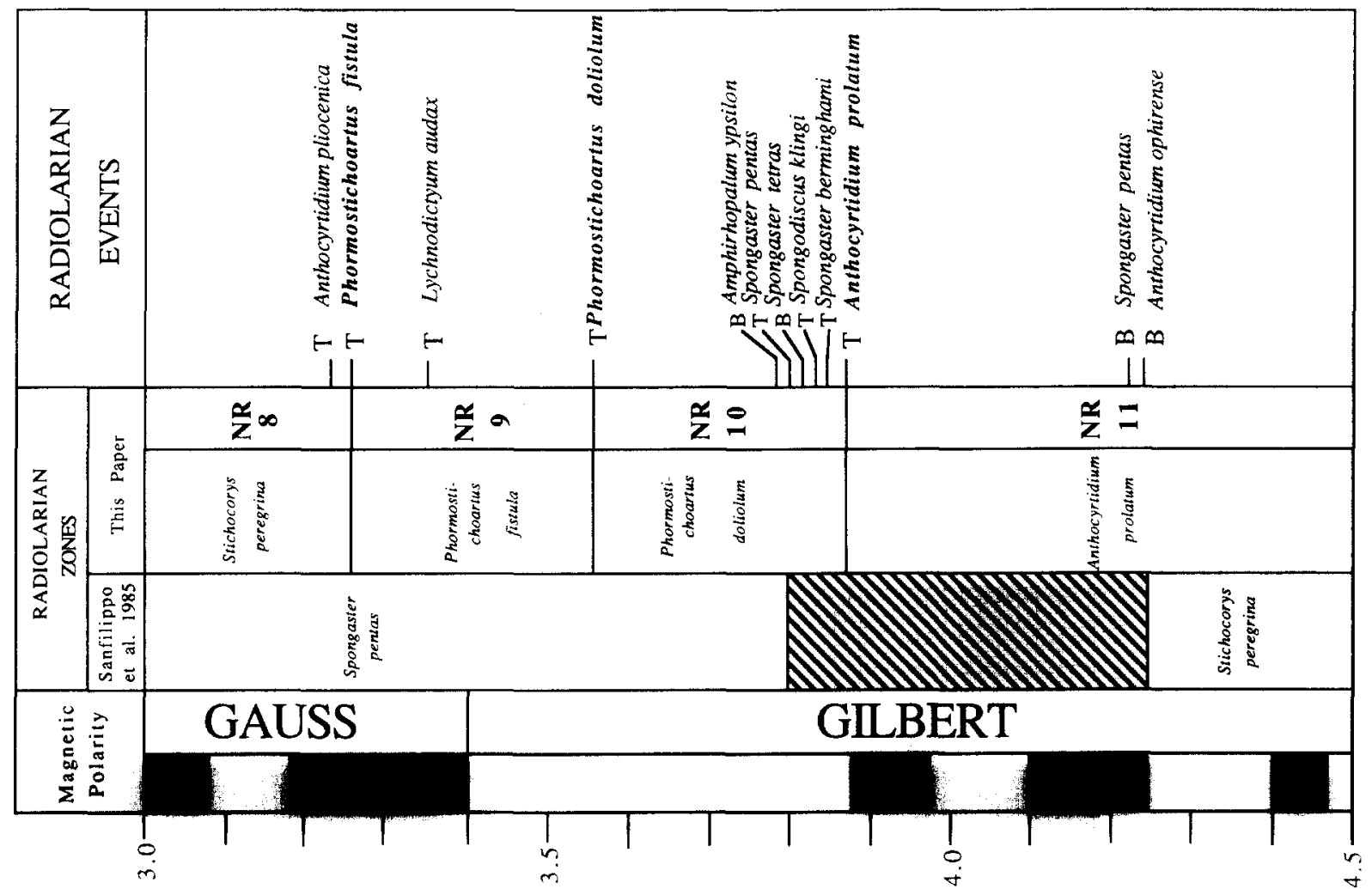

Fig. 8. Summary of proposed radiolarian zonation, radiolarian events, and paleomagnetic stratigraphy for the Pliocene and Pleistocene of the tropical Indian Ocean. Geomagnetic polarity time scale from Berggren et al. (1985a).

Morphotypic bottom of Collosphaera tuberosa (approx. 0.58 Ma) to morphotypic top of Stylatractus universus (0.42 Ma).

(Nr. 4) Amphirhopalum ypsilon IntervalChronozone [Nigrini, 1971; Caulet, 1979 (partim.) ]

Morphotypic top of Anthocyrtidium angulare (ca. 1.0 Ma) to morphotypic bottom of Collosphaera tuberosa (ca. $0.58 \mathrm{Ma}$ ).

Events included in this Zone are:

Tm Anthocyrtidium nosicaae (diachronous)

Tm Pterocorys campanula

$\mathrm{Bm}$ Pterocorys hertwigii

$\mathrm{Bm}$ Anthocyrtidium euryclathrum (Indian Ocean only)

(Nr. 5) Anthocyrtidium angulare IntervalChronozone [Nigrini, 1971; Caulet, 1979 (partim.)]

Morphotypic top of Pterocanium prismatium (1.55 Ma) to morphotypic top of Anthocyrtidium angulare (1.0 Ma).

Events included in this Zone are:

$\mathrm{Bm}$ Lamprocyrtis nigriniae

Tm Lamprocyrtis neoheteroporos

Tm Anthocyrtidium michelinae

(Nr. 6) Pterocanium prismatium IntervalChronozone [Riedel and Sanfilippo, 1970, emend. 1978, emend. Sanfilippo et al., 1985 (partim.); Caulet, 1979 (partim.)]

Morphotypic top of Anthocyrtidium jenghisi (ca. $2.35 \mathrm{Ma}$ ) to morphotypic top of Pterocanium prismatium (1.55 $\mathrm{Ma}$ ).

Events included in this Zone are:

$\mathrm{Bm}$ Anthocyrtidium angulare

Bm Pterocorys zancleus

Tm Theocorythium vetulum 
(Nr. 7) Anthocyrtidium jenghisi IntervalChronozone (non NR 7 of Caulet, 1979)

Morphotypic top of Stichocorys peregrina (2.65 Ma) to morphotypic top of Anthocyrtidium jenghisi $(2.35 \mathrm{Ma})$.

Events included in this Zone are:

$\mathrm{Bm}$ Theocalyptra davisiana

$\mathrm{Bm}$ Lamprocyrtis neoheteroporos (diachronous)

$\mathrm{Bm}$ Theocorythium trachelium (diachronous)

(Nr. 8) Stichocorys peregrina IntervalChronozone (non Stichocorys peregrina Zone of Riedel and Sanfilippo, 1970, emend. 1978)

Morphotypic top of Phormostichoartus fistula (ca. 3.25 Ma) to morphotypic top of Stichocorys peregrina (2.65 $\mathrm{Ma})$.

Events included in this Zone are:

Tm Anthocyrtidium ehrenbergi (diachronous)

Tm Anthocyrtidium pliocenica (diachronous)

(Nr. 9) Phormostichoartus fistula IntervalChronozone

Morphotypic top of Phormostichoartus doliolum (ca. $3.55 \mathrm{Ma}$ ) to morphotypic top of Phormostichoartus fistula (ca. 3.25 Ma).

Events included in this Zone are:

Tm Lychnodictyum audax

(Nr. 10) Phormostichoartus doliolum Interval-Chronozone

Morphotypic top of Anthocyrtidium prolatum (ca. 3.87 Ma) to morphotypic top of Phormostichoartus doliolum (3.55 Ma).

Events included in this Zone are:

Bm Amphirhopalum ypsilon

Tm Spongaster pentas (diachronous)

$\mathrm{Bm}$ Spongaster tetras

Tm Spongodiscus klingi

Tm Spongaster berminghami (diachronous)

\section{(Nr. 11) Anthocyrtidium prolatum Range} Chronozone

Defined by the range of Anthocyrtidium prolatum (ca. 4.7 Ma to $3.87 \mathrm{Ma}$ ).

Events included in this Zone are:

Bm Spongaster pentas (diachronous)

Bm Anthocyrtidium ophirense (diachronous)

\section{Discussion}

We have identified thirty-three radiolarian datum levels in the Plio-Pleistocene (0.0-4.5 $\mathrm{Ma}$ ) of the tropical Indian Ocean, and have calibrated each to the paleomagnetic time scale. Nineteen of these events are here identified and calibrated for the first time, thereby allowing a substantial increase in the degree of stratigraphic resolution which is possible in the late Neogene (e.g. Riedel and Sanfilippo, 1978, fig. 1; Sanfilippo et al., 1985, fig. 2, p. 640). Some of these events can be calibrated with high precision (i.e., less than 0.1 m.y.). Others may be less precise when their FAD's or LAD's are blurred as a result of apparently discontinuous occurrences, some of which may be artifacts of mixing or contamination in specific cores. We have assessed the relative reliability of each datum level (see remarks in previous section) and on this basis have recommended a revision in the tropical radiolarian zonation for the Pliocene-Pleistocene.

Our revised zonation derives from our observations of the unsatisfactory nature of the Spongaster berminghami $\rightarrow S$. pentas $\rightarrow S$. tetras lineage as a criteria for subdividing the PlioPleistocene in the Indian Ocean. The two earlier species in the lineage are relatively rare in our Indian Ocean cores compared with their Pacific abundances, and in many samples are missing entirely. Moreover some of the events in the lineage are notably non-synchronous (Johnson and Nigrini, 1985; this paper, Table VII). For this reason we have assessed the degree of reliablility of each of the 33 radiolarian events and have chosen ten of these providing the most reliable criteria for stratigraphically subdividing the late Neogene.

We note that our zonation and sequence of events includes some of the same events recognized by Caulet $(1982,1986 \mathrm{~b})$ in proposing a mid-latitude late Neogene zonation. However, there are notable differences in the diversity and species composition of the assemblages in moving from tropical to temperate latitudes, and thus it seems important to establish and cali- 
brate the zonations from the two regions independently. After such calibration, the degree of morphological similarity of taxa and the synchroneity of events between low and middle latitudes can be assessed more reliably than is possible at the present time.

We also note that an alternative approach to our assessment of non-synchroneity would be to employ graphical correlation procedures (e.g. Barron et al., 1985; Dowsett, 1987; Prell et al., 1987 ). Such a procedure is especially valuable when there exists a well-chosen reference section against which all others can be mapped, such as core VM28-238 which serves as a reference for graphic correlational techniques in fine-tuning the isotope time scale of the late Pleistocene (e.g. Prell et al., 1987). When we have extended our analyses to additional prePleistocene Indian Ocean cores (e.g. Table I, Part B), it may then be possible to identify a single core to serve as a reference section, and thereby use graphic techniques to further refine the positions of datum levels (Fig. 8).

We here have observed that a significant number of radiolarian datum levels (roughly one-third of all those examined) are indeed diachronous between the Indian and Pacific Ocean (Table VII), yet the patterns may not be as simple as those we suggested earlier (Johnson and Nigrini, 1985). It appears that first- and last-occurrences are comparably represented among the diachronous events. Moreover, there seems to be no clear pattern of FAD's occurring in the Indian Ocean prior to their appearance in the Pacific. We here encourage a re-assessment of possibly diachronous events in all microfossil groups, as a means to document more fully this effect and allow us to begin to assess its oceanographic and evolutionary implications.

\section{Summary and conclusions}

Thirty-three radiolarian events have been documented in the Pliocene-Pleistocene of the tropical Indian Ocean (0.0-4.5 Ma), and calibrated to the paleomagnetic reversal time scale. Nineteen of these events are described and calibrated here for the first time. Twelve of the events are clearly diachronous between the tropical Indian and Pacific Oceans. On the basis of our assessment of the reliability and degree of synchroneity of each event, we have proposed a revised radiolarian zonation, based on selecting as zonal markers those events which are demonstrably synchronous. We anticipate that our revision may allow increased stratigraphic resolution in tropical sediment cores. Moreover, our work points to a continuing need to question the presumption of biostratigraphic synchroneity, and to use independent correlational techniques (e.g. isotopic and paleomagnetic stratigraphy) to re-assess the degree of synchroneity of each chosen datum level.

\section{Acknowledgements}

This project was funded under N.S.F. Grant No. OCE82-00668, and under CNRS (France) Grant No. 160055 (to JPC). We thank R. Lotti for assistance in obtaining core samples at Lamont-Doherty Geological Observatory, and Doug Bergersen for assistance in sample preparation. Samples from core MD81-369 were kindly provided by the Muséum National d'histoire Naturelle (Paris). We thank Lloyd Keigwin, Kozo Takahashi, Lloyd Burckle and James Hays for reviewing the manuscript. 


\section{TABLE II}

Presence of stratigraphically important radiolarians in each sample examined from core VM34-53. Left-hand columns indicate the sub-bottom depth (in $\mathrm{cm}$ ) and the estimated age ( $\mathrm{Ma}$ ) of each sample, using the isotopic and paleomagnetic calibrations of Figs. 2 and 3. Explanation of symbols in text.

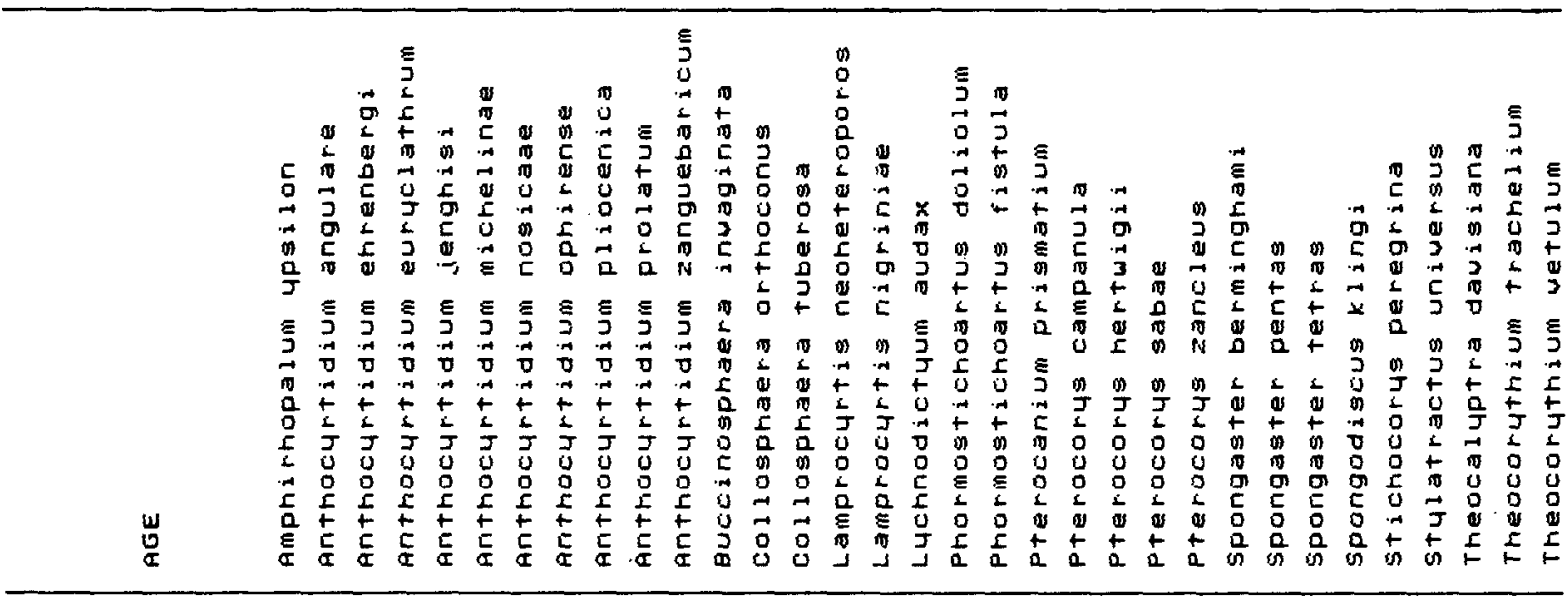

$\begin{array}{ll}115 & -09 \\ 135 & .10 \\ 155 & .12 \\ 175 & .14 \\ 195 & .16 \\ 216 & .18 \\ 236 & -21 \\ 255 & .23 \\ 277 & .25 \\ 295 & -28 \\ 314 & -30 \\ 336 & .33 \\ 355 & -37 \\ 373 & .41 \\ 396 & -47 \\ 416 & .51 \\ 436 & .55 \\ 455 & -58 \\ 475 & -60 \\ 505 & .63 \\ 526 & -65 \\ 536 & .66 \\ 545 & .67 \\ 552 & -68\end{array}$

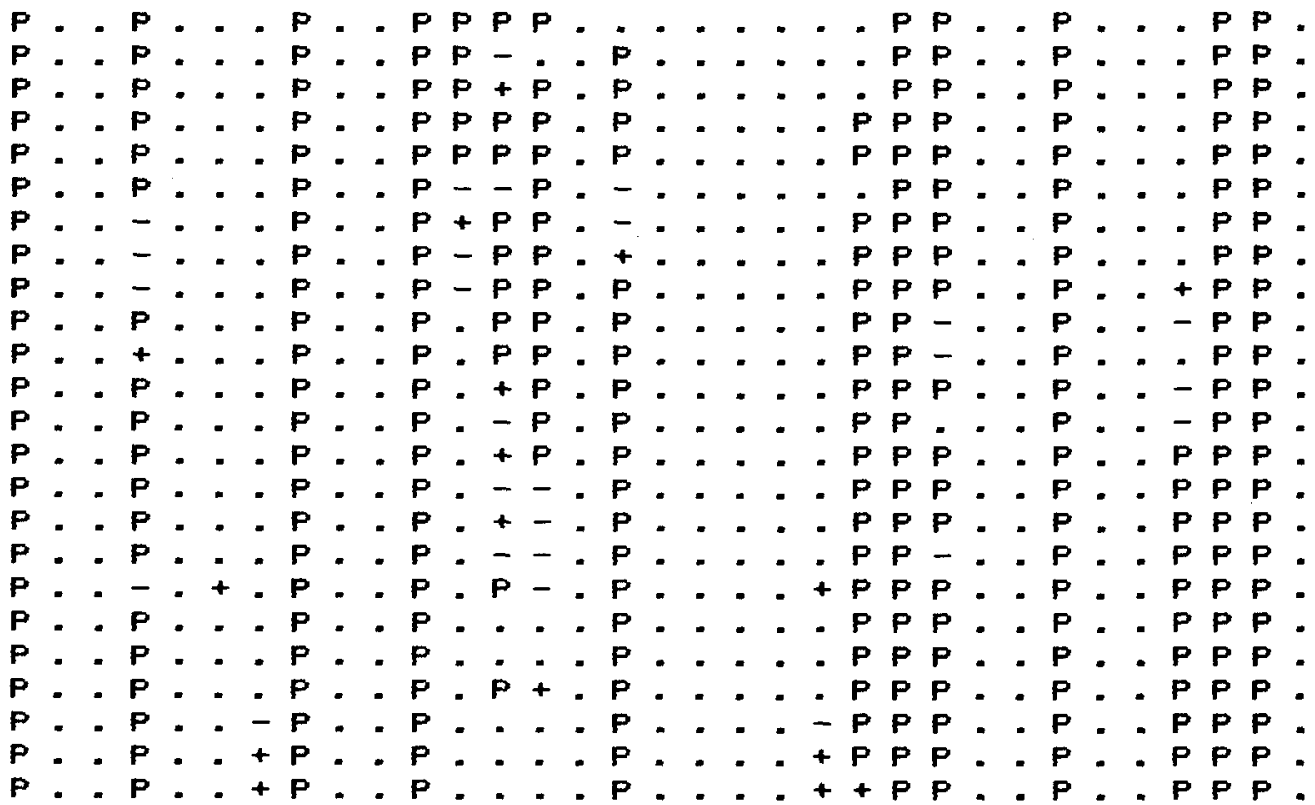




\section{TABLE III}

Presence of stratigraphically important radiolarians in each sample examined from core RC14-22. Ages of samples are derived from paleomagnetic calibrations of Fig. 4. Explanation of symbols in text.

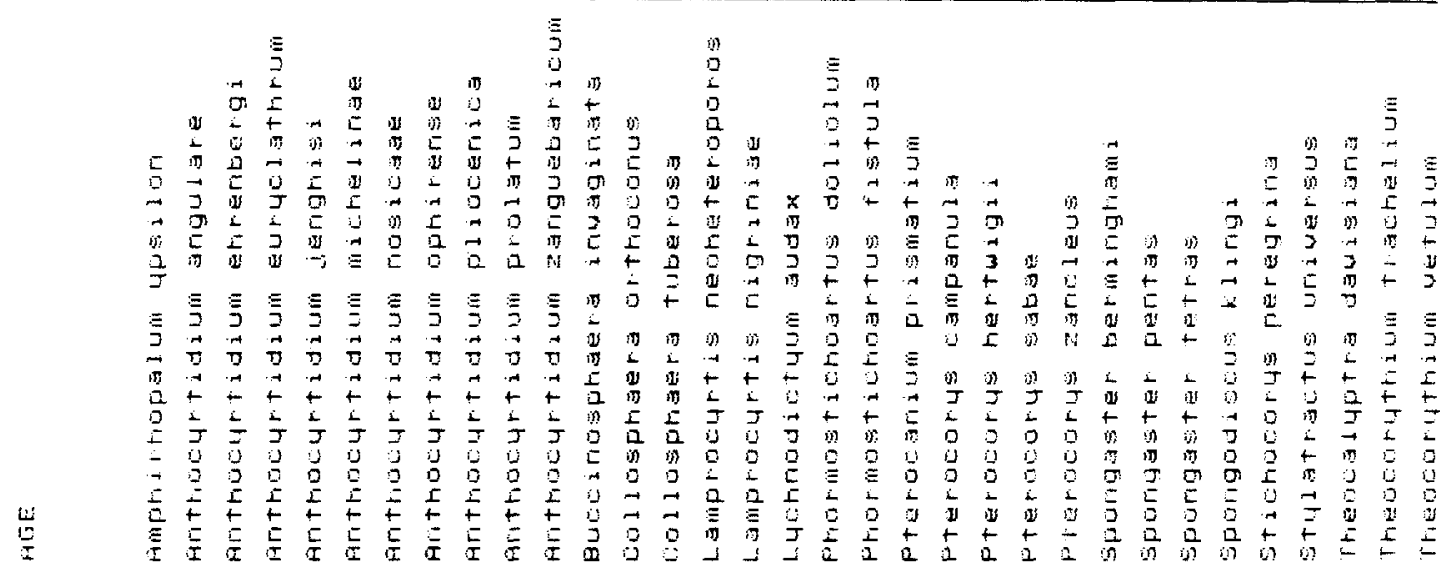

\begin{tabular}{|c|c|c|c|c|c|c|c|c|c|c|c|c|c|c|c|c|c|c|c|c|c|c|c|c|c|c|}
\hline 1010 & 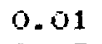 & E & & - & - & * & $P$ & • & $P$ & $F$ & $-F$ & $P$ & $F$ & • & 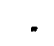 & • & - & $P$ & $F$ & $P$. & - & $F$ & - & - & $P$ & $r$ \\
\hline 2100 & -12 & P & 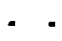 & - & 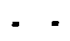 & . & $\mathbf{F}$ & - & $P$ & $\mathbf{P}$ & +1 & $P$ & $P$ & 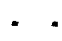 & . & . & . & $\mathbf{P}$ & $P$ & $?$ & - & $F$ & & . & $P$ & $P$ \\
\hline 120 & 15 & $P$ & - & - & - & - & $\boldsymbol{P}$ & . & $F$ & - & $-F$ & $P$ & + & . & & $=$ & . & - & $F$ & $F$ & . & $F$ & & . & $P$ & $P$ \\
\hline 1 & 17 & 5 & . & - & 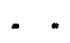 & . & $P$ & . & $F$ & - & $P F$ & $P$ & $P$ & - & . & . & . & - & $F$ & 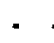 & . & $F$ & & . & $F$ & $P$ \\
\hline 1 & 20 & $r$ & - & $P$ & 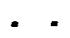 & 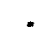 & $F$ & . & $F$ & 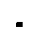 & $F$ & $P$ & $P$ & - & & = & + & + & $P$ & . & . & $\mathbf{F}$ & & - & + & $P$ \\
\hline 1 & 22 & & & $P$ & - & " & $F$ & . & $F$ & . & $P$ & $\mathbf{P}$ & $F$ & . & & - & 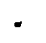 & $F$ & $P$ & . & - & $\mathbf{F}$ & & . & & $P$ \\
\hline 10 & 24 & & & $P$ & - & . & $F$ & . & $P$ & - & $+F$ & $P=$ & $P$ & & 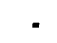 & . & - & $P$ & $P$ & $F$ & . & $P$ & & . & & $P$ \\
\hline 1220 & 26 & & & 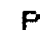 & - & . & $P$ & . & $P$ & . & $P F$ & $P=$ & $P$ & . & . & . & - & $\mathbf{P}$ & $\mathrm{P}$ & $\mathbf{P}$ & . & $P$ & & 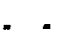 & & 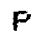 \\
\hline 24 & 29 & r & & $P$ & 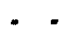 & • & $\boldsymbol{F}$ & - & $F$ & - & $+F$ & $P$ & $P$ & - & - & . & . & $P$ & $\mathbf{P}$ & $P$ & . & $F$ & & . & & $P$ \\
\hline 260 & 31 & F & 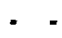 & $P$ & . & . & $P$ & . & $P$ & - & $-f$ & $P$ & $F$ & 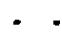 & - & . & . & $F$ & $P$ & $P$ & . & $\mathbf{P}$ & & . & 5 & $P$ \\
\hline 280 & 35 & 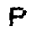 & . & 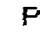 & 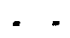 & . & $P$ & - & $F$ & . & $-F$ & $P$ & $F$ & - & - & . & . & $P$ & $F$ & $?$ & . & $F$ & & . & 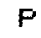 & $P$ \\
\hline 300 & .35 & & - & $P$ & 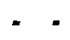 & - & $\mathbf{P}$ & . & - & 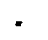 & $+F$ & $P=$ & - $P$ & 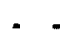 & 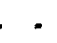 & . & . & $\mathbf{P}$ & $F$ & $=$ &. & $F$ & & . & 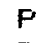 & $F$ \\
\hline 320 & 57 & & & $F$ & - & . & $P$ & - & $P$ & - & +1 & + & $* F$ & . & . & . & - & $F$ & $P$ & - & . & $P$ & & . & $P$ & 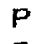 \\
\hline 0340 & 0.40 & & - & 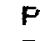 & - & - & $P$ & . & - & $=$ & -1 & + & 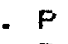 & - & . & - & . & $\mathbf{P}$ & $\mathbf{P}$ & . & . & $F$ & & . & & $P$ \\
\hline 0360 & 2 & & 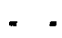 & $P$ & - & - & $P$ & . & $F$ & . & + &.- & $F$ & . & . & . & . & $\boldsymbol{F}$ & $P$ & ${ }^{\circ}$ & . & $F$ & & - & & $P$ \\
\hline 0 & 5 & & • & $P$ & - & + & $\mathbf{P}$ & - & - & - & - & - & . & . & . & . & . & $F$ & $P$ & . & . & $F$ & & - & $P$ & $P$ \\
\hline 400 & 47 & r & . & $\mathbf{P}$ & . & - & $\mathbf{P}$ & - & -+ & - & + & - & $=\mathbf{P}$ & 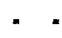 & 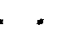 & - & . & $F$ & $F$ & " & . & $\mathbf{P}$ & . & + & $\rho$ & $P$ \\
\hline 420 & .50 & P & 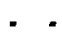 & $\mathbf{P}$ & 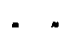 & - & $P$ & - & $-P$ & * & $\mathbf{P}$ &.- & $=P$ & - & - & 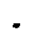 & . & $P$ & $P$ & $\dot{ }$ & * & $\varphi$ & 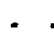 & $P$ & 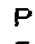 & $p$ \\
\hline 440 & 52 & 5 & 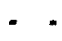 & $P$ & 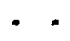 & $"$ & $\boldsymbol{F}$ & - & - $P$ & - & $P$ & + & - $P$ & 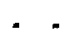 & 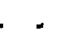 & - & 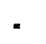 & $F$ & $F$ & $F$ & . & $F$ & - & - & $F$ & $P$ \\
\hline 9460 & 5 & & - & $P$ & " & - & $F$ & - & $P$ & - & $P+$ & $+=$ & $=F$ & - & - & - & - & $P$ & $P$ & - & - & $P$ & 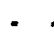 & . & $P$ & $P$ \\
\hline$a$ & 17 & & . & $P$ & - & . & $P$ & - & $F$ & - & - & + & $F$ & . & . & . & . & $F$ & $P$ & . & • & 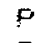 &. & . & $P$ & $P$ \\
\hline 0 & 9 & & - & 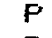 & " & - & $P$ & - & $F$ & - & - & - & $P$ & - & . & $\cdot$ & - & $\mathbf{P}$ & $P$ & $=$ & - & $P$ & - & - & $P$ & $F$ \\
\hline 20 & 61 & & . & $\mathbf{P}$ & - & + & $P$ & - & $P$ & $=$ & $\mathbf{P}$ & $-\cdot$ & $\cdot F$ & - & . & . & + & $\boldsymbol{F}$ & $F$ & + & - & $P$ & $=$ & $F$ & $P$ & $P$ \\
\hline 540 & 64 & 5 & 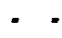 & $\mathbf{P}$ & 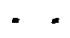 & - & $F$ & - & $-P$ & - & - & - & $=-$ & - & - & - & - & $P$ & $P$ & - & - & $F$ &. & - $P$ & $F$ & $P$ \\
\hline 560 & 66 & 5 & 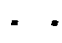 & $P$ & 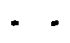 & - & $P$ & - & $P$ & 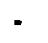 & - & = & - $P$ & . & 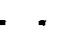 & . & - & $P$ & $P$ & - & - & $P$ & - & - $P$ & $P$ & $F$ \\
\hline 580 & 69 & & - & $F$ & . & - & $P$ & - & - & $=$ & - & & - $P$ & - & $=$ & - & $?$ & $\mathbf{P}$ & $\mathbf{P}$ &. & - & $P$ & . & - $P$ & $P$ & $F$ \\
\hline 0600 & 1 & & - & $P$ & - & * & $P$ & - & $F$ & - & $=$ & - & - $P$ & . & . & . & $\mathbf{F}$ & $F$ & $F$ & : & - & $P$ & - & - $P$ & $F$ & $P$ \\
\hline 620 & 3 & & - & $F$ & - & $=$ & $F$ & - & $F$ & - & $F$ & - & $=-$ & . & - & . & $P$ & $F$ & $F$ & $\boldsymbol{F}$ & $=$ & $P$ & $=$ & - & $P$ & $F$ \\
\hline 640 & 76 & & 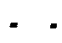 & $P$ & - & + & $F$ & . & - & - & - & . & - $F$ & 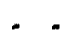 & . & - & $P$ & + & $F$ & $P$ & . & $F$ &. & . + & $\mathbf{P}$ & $\mathbf{P}$ \\
\hline 1660 & 78 & $r$ & - & $F$ & - & $P$ & $P$ & - & $-P$ & - & - & & - $P$ & & - & - & $F$ & - & $F$ & - & - & $P$ & * & - $P$ & $F$ & $P$ \\
\hline 690 & 80 & $F$ & 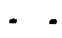 & ? & 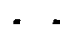 & 9 & $P$ & - & $F$ & & - & & $=\quad+$ & & . & . & $P$ & - & $P$ & . & . & $F$ & . & . $F$ & $F^{\prime}$ & $F$ \\
\hline 5700 & .82 & $\mathbf{P}$ & - & $F$ & 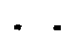 & $P$ & $P$ & . & $=P$ & & - & * & $-F$ & & - & . & $F$ & - & $\mathrm{F}$ & - & . & $P$ & - & $=P$ & $P$ & $F$ \\
\hline 720 & .84 & & & $P$ & • & $\mathbf{F}$ & $P$ & . & - $F$ & & + & & - $P$ & & $\bullet$ &. & $P$ & - & $F$ & $P$ & . & $P$ & - & $=-$ & $F$ & $\mathbf{P}$ \\
\hline 740 & 87 & & & - & - & $P$ & $F$ & - & $P$ & & . & $+=$ & $-F$ & & - & • & $F$ & + & $F$ & $?$ & • & $F$ & - & $=-$ & $P$ & $F^{\prime}$ \\
\hline 760 & 39 & & & + &. & $P$ & $\beta^{\prime}$ & - & $P$ & - & . & - &.$P$ & & - & - & $F$ & - & $F$ & $F$ & . & $P$ & $=$ & . $=$ & 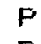 & $F$ \\
\hline 0 & & & - & + & . & $P$ & $P^{*}$ & & $F$ & . & 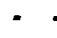 & & $-F$ & & - & - & $P$ & - & $P$ & - & & $P$ & $=$ & - $P$ & $r$ & $\beta$ \\
\hline 800 & & F & - & - & - & $P$ & $F$ & - & $P$ & & 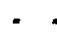 & & $+F$ & & - & & $P$ & - & $P$ & - & & $P$ & - & - $P$ & $P$ & $P$ \\
\hline 820 & 96 & r & - & - & 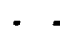 & $P$ & $P$ & - & $P$ & & . & & ++ & & . & & $P$ & & $P$ & - & & $P$ & . & - $\mathbf{P}$ & $P$ & $P$ \\
\hline 840 & 0.99 & $P$ & - & - & = & $P$ & $F$ & . & $F$ & & & & -- & & $=$ & & & & $P$ & & & $\mathbf{P}$ & & $F$ & $P$ & \\
\hline
\end{tabular}




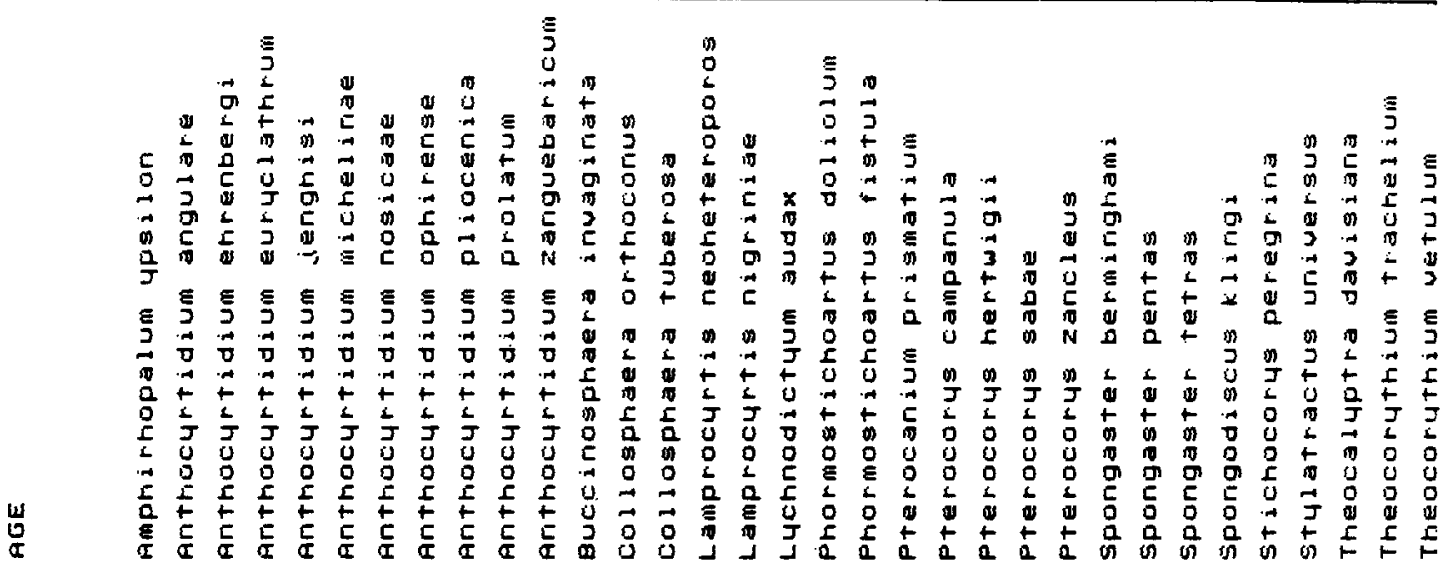

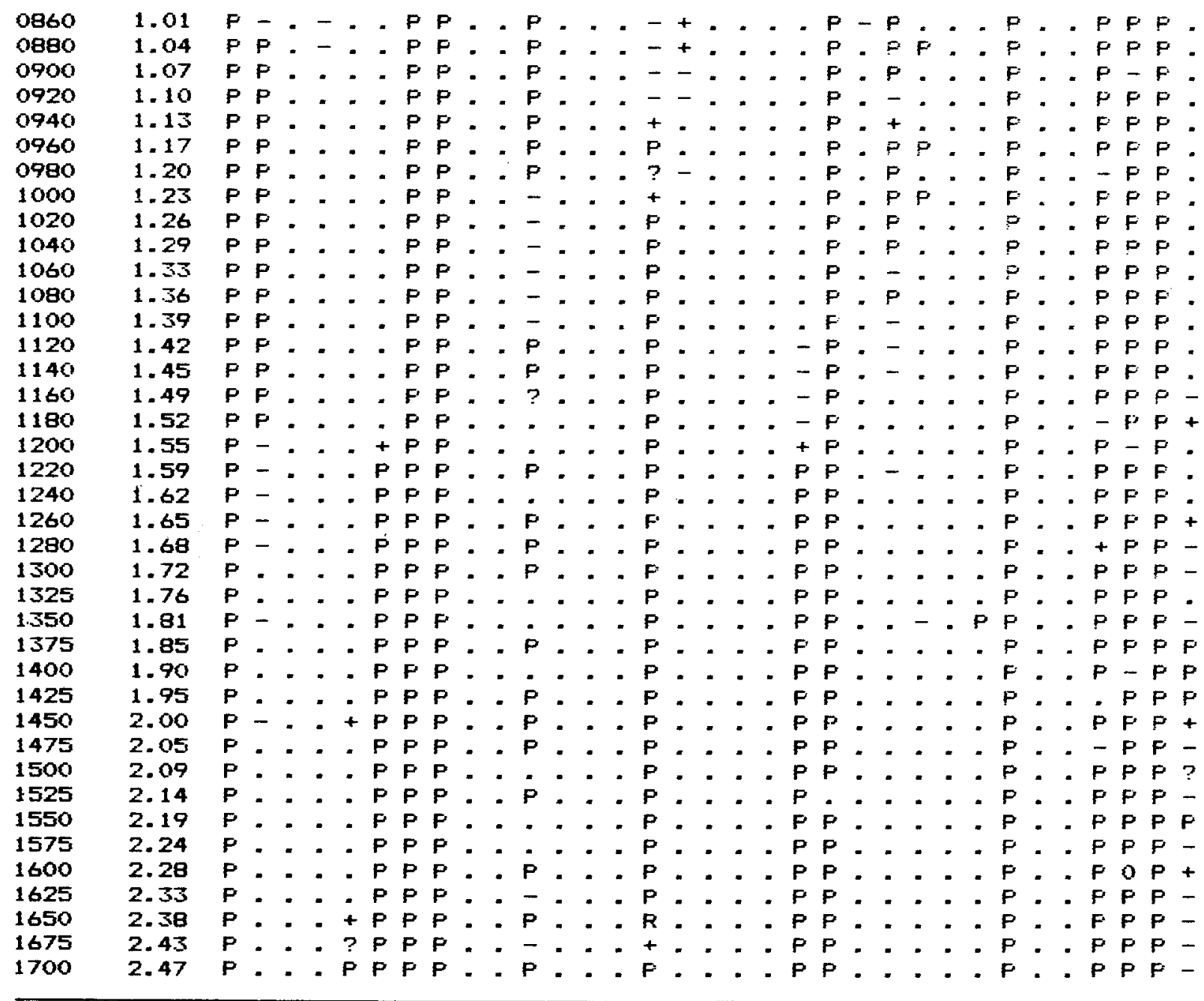




\section{TABLE IV}

Presence of stratigraphically important radiolarians in each sample examined from core MD81-369. Ages of samples are derived from paleomagnetic calibrations of Fig. 5. Explanation of symbols in text.

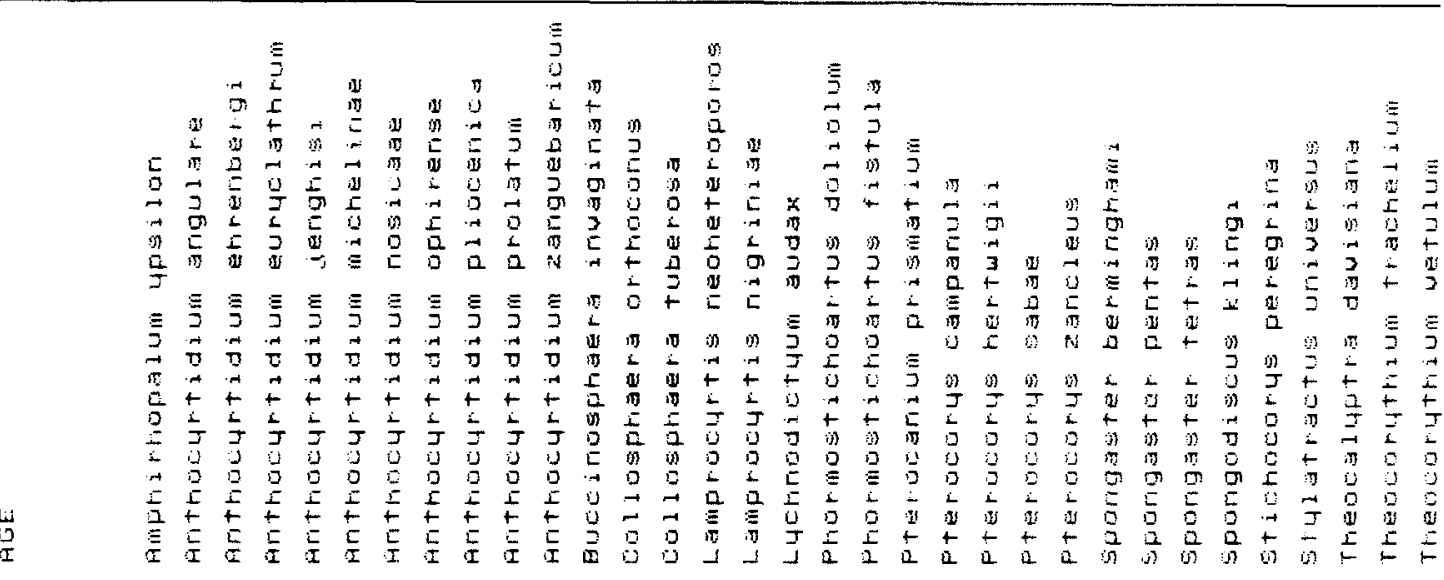

$\begin{array}{ll}0 & . \\ 60 & .55 \\ 70 & .57 \\ 80 & .60 \\ 90 & .62 \\ 100 & .64 \\ 110 & .67 \\ 120 & .69 \\ 130 & .72 \\ 140 & .75 \\ 150 & .78 \\ 160 & .91 \\ 170 & .84 \\ 180 & .87 \\ 190 & .90 \\ 198 & .92 \\ 202 & .92 \\ 210 & .94 \\ 220 & .95 \\ 230 & .97 \\ 240 & .99 \\ 250 & 1.02 \\ 260 & 1.04 \\ 270 & 1.07 \\ 280 & 1.09 \\ 290 & 1.12 \\ 300 & 1.14 \\ 310 & 1.17 \\ 320 & 1.19 \\ 330 & 1.22 \\ 340 & 1.24 \\ 348 & 1.26 \\ 354 & 1.28 \\ 360 & 1.30 \\ 370 & 1.32 \\ 380 & 1.34 \\ 390 & 1.37 \\ 400 & 1.39 \\ 410 & 1.42 \\ 420 & 1.44 \\ & \\ 1.90 \\ 1.90\end{array}$

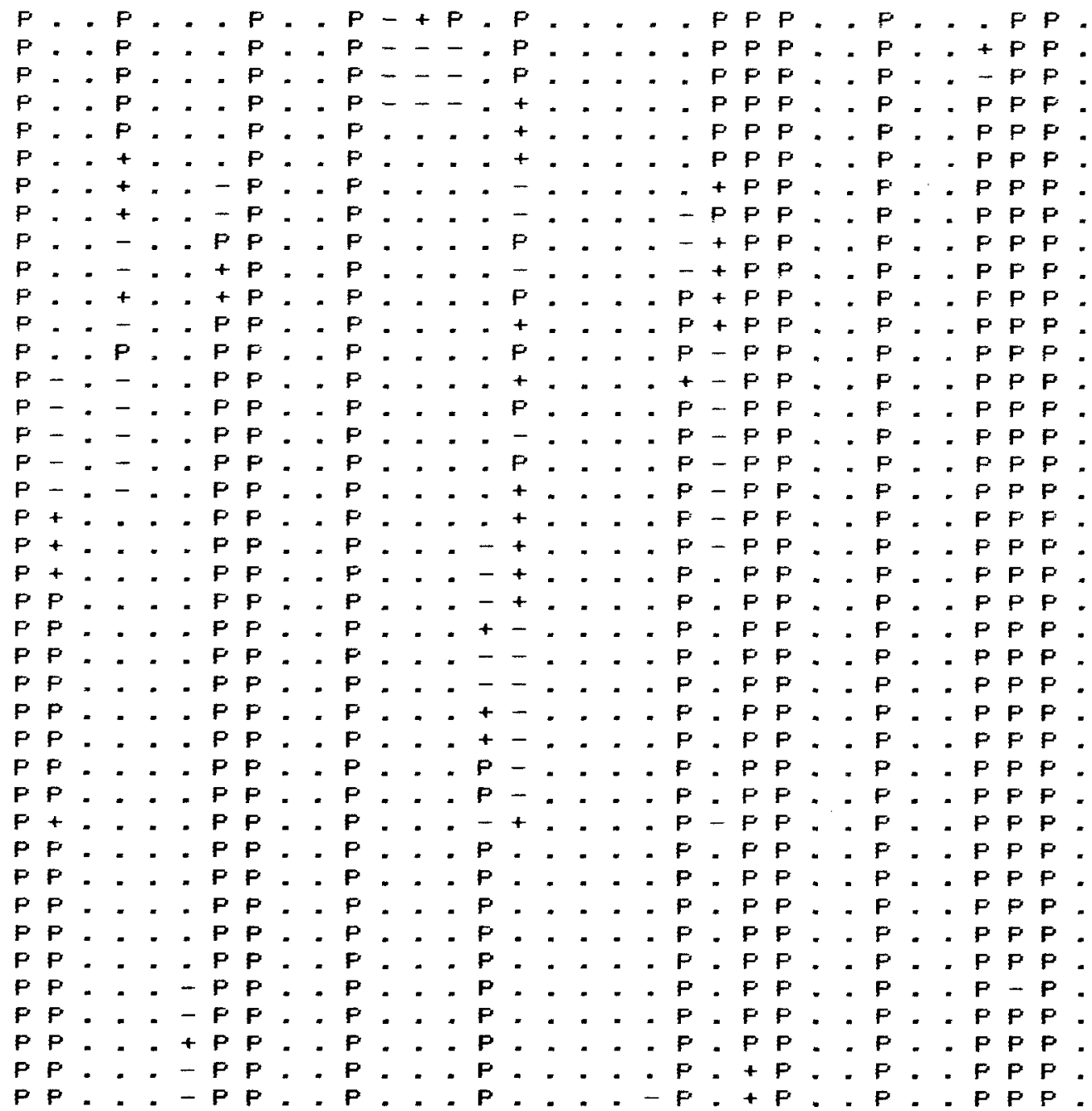




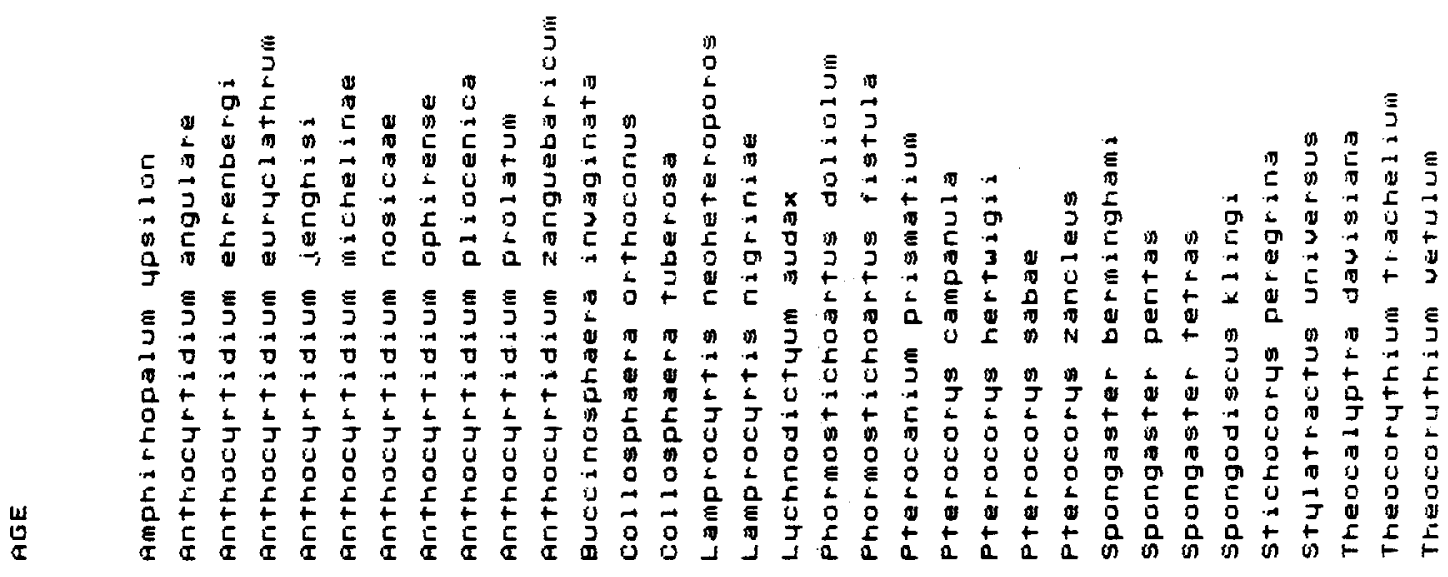

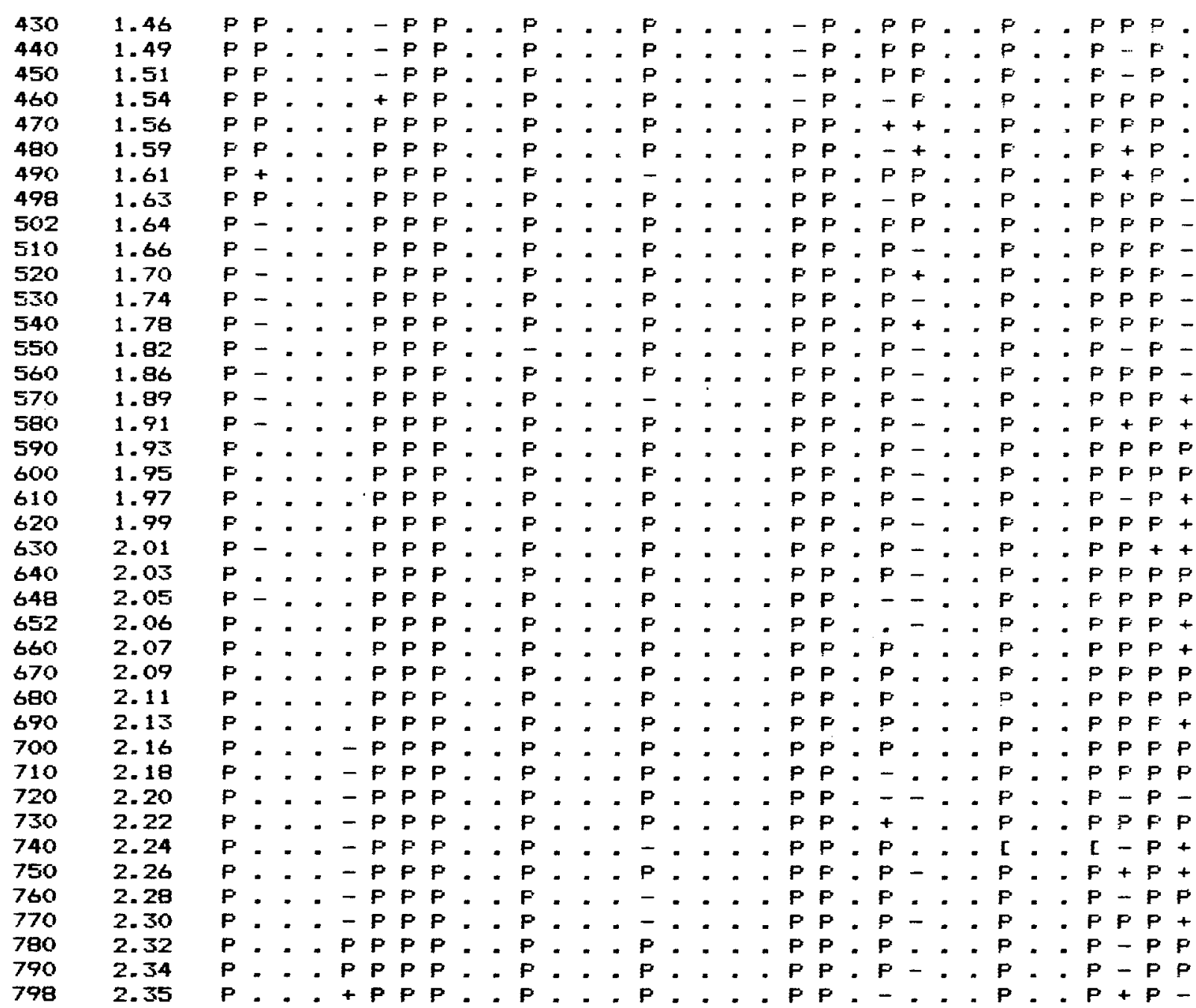




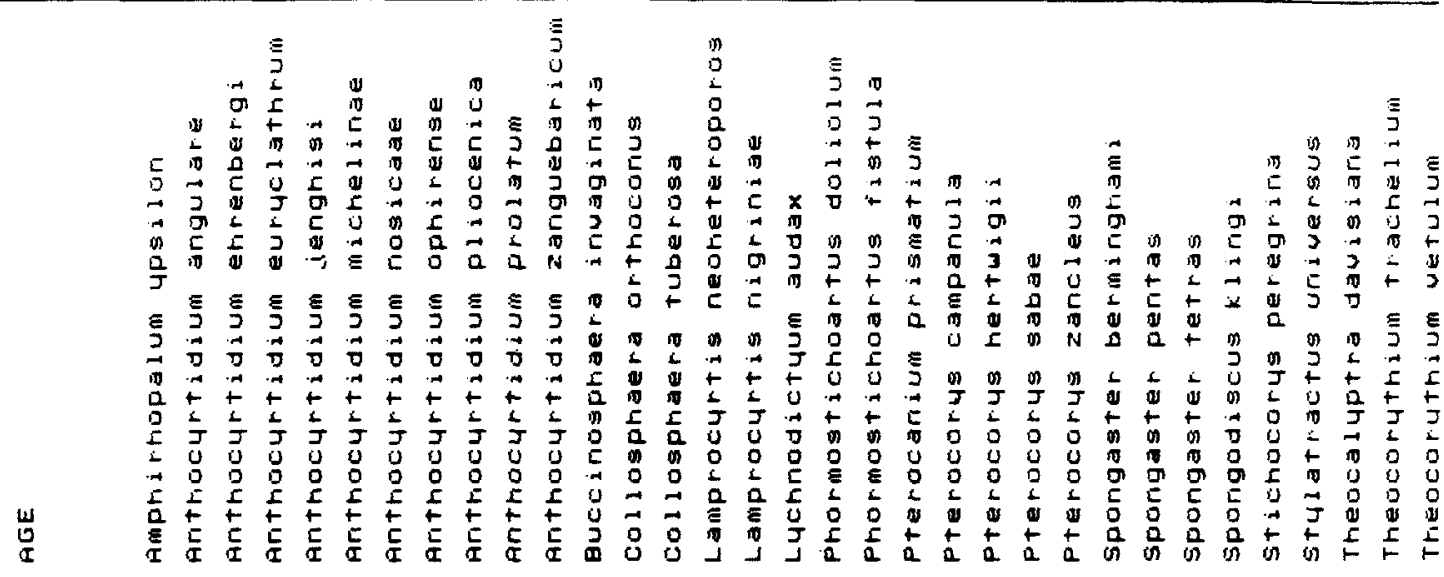

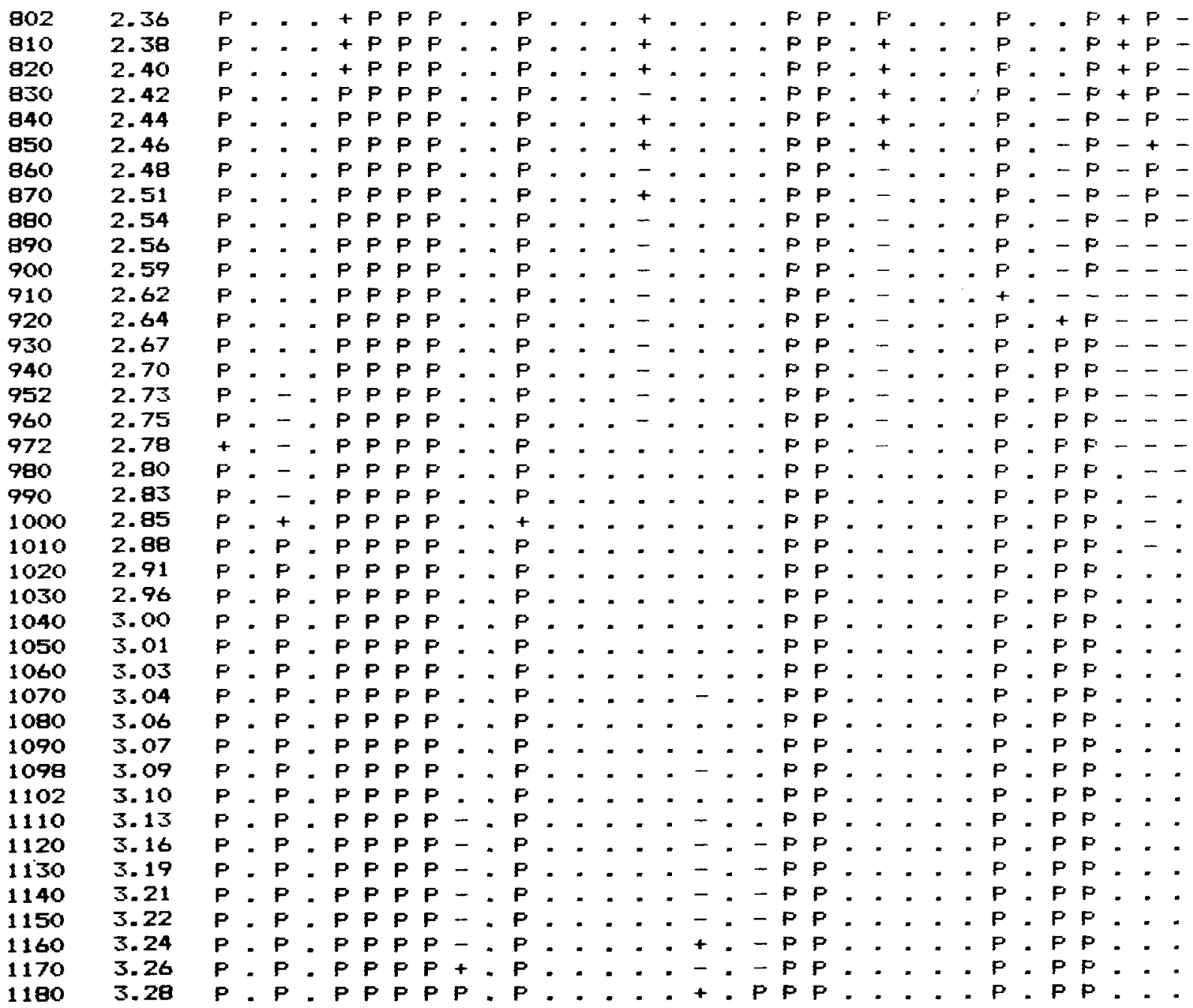




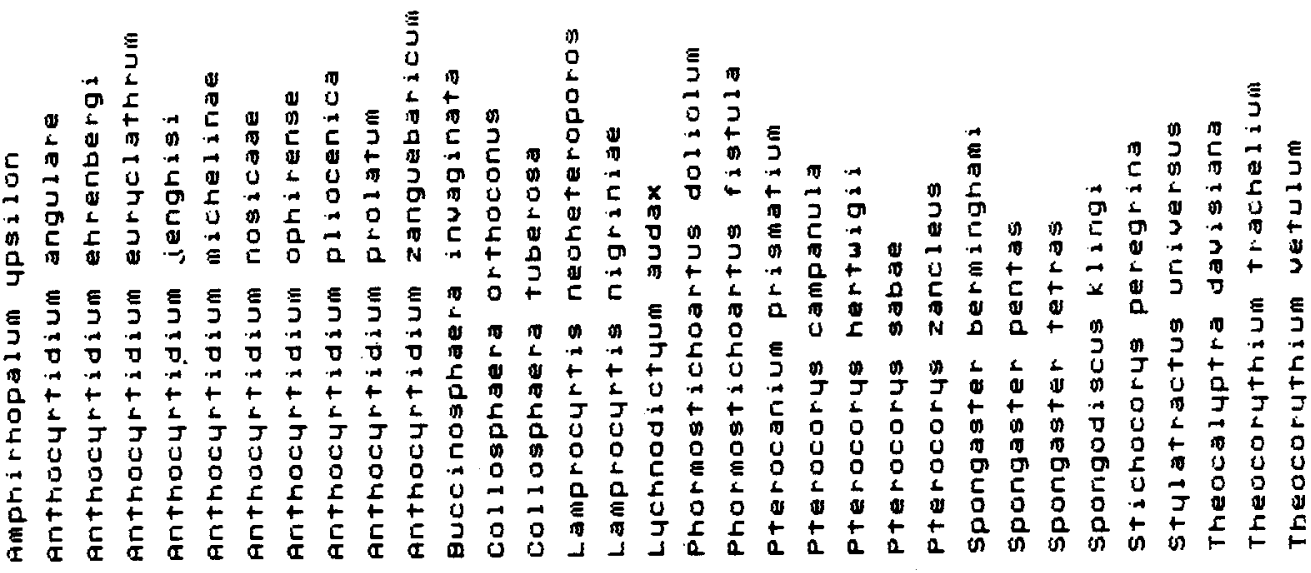

$\begin{array}{ll}1190 & 3.29 \\ 1200 & 3.31 \\ 1210 & 3.33 \\ 1220 & 3.35 \\ 1230 & 3.37 \\ 1240 & 3.38 \\ 1248 & 3.40 \\ 1252 & 3.40 \\ 1260 & 3.42 \\ 1270 & 3.44 \\ 1280 & 3.46 \\ 1292 & 3.48 \\ 1300 & 3.49 \\ 1310 & 3.51 \\ 1320 & 3.53 \\ 1330 & 3.55 \\ 1340 & 3.57 \\ 1350 & 3.59 \\ 1360 & 3.61 \\ 1370 & 3.63 \\ 1380 & 3.65 \\ 1390 & 3.66 \\ 1430 & 3.74 \\ 1440 & 3.76 \\ 1450 & 3.78 \\ 1460 & 3.80 \\ 1470 & 3.81 \\ 1480 & 3.83 \\ 1490 & 3.85 \\ 1500 & 3.87 \\ 1510 & 3.90 \\ 1520 & 3.93 \\ 1530 & 3.96 \\ 1540 & 3.98 \\ 1548 & 3.99 \\ 1552 & 4.00 \\ 1560 & 4.01 \\ 1570 & 4.02 \\ 1580 & 4.04 \\ 1590 & 4.05 \\ & \end{array}$

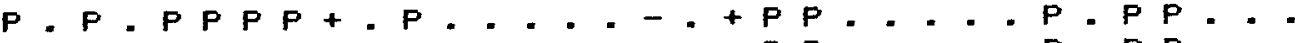

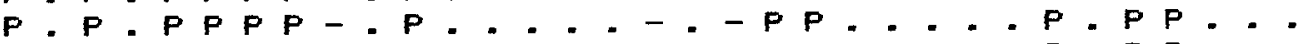

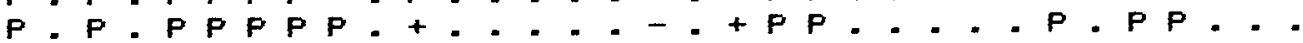

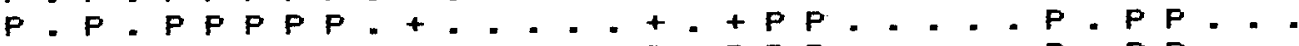

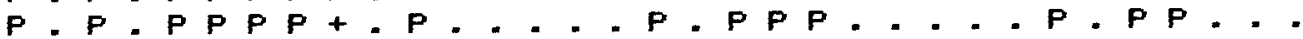

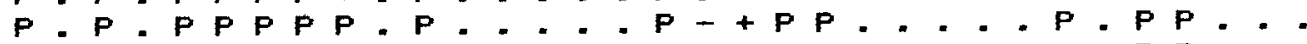

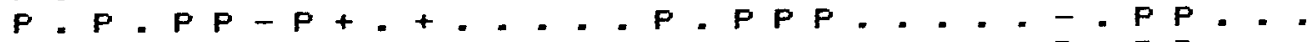

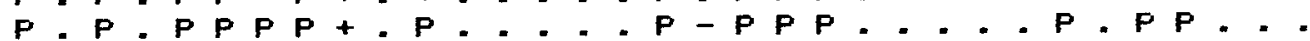

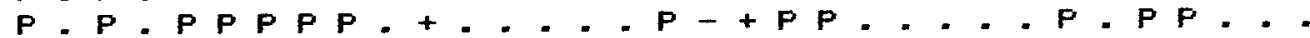

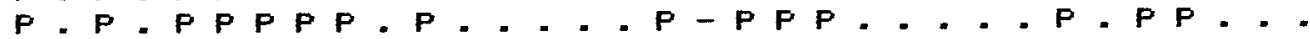

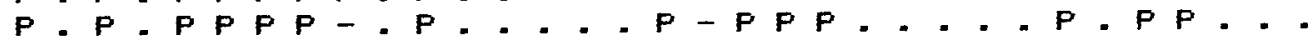

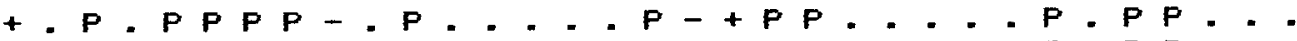

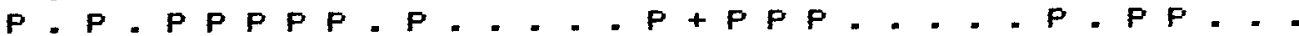

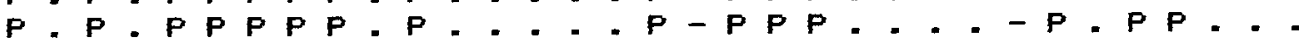

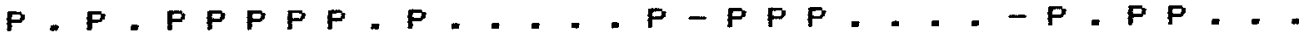

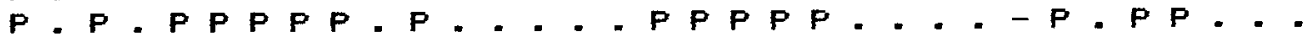

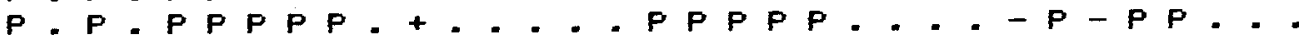

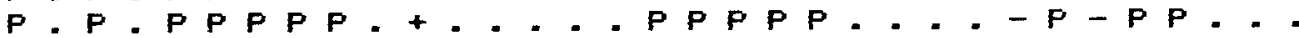

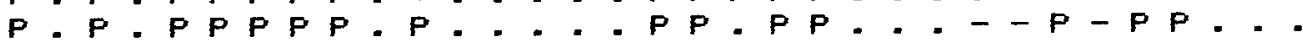
+ + $P$-PPPPP.P.... $P P P-P+. .--P-P P$.

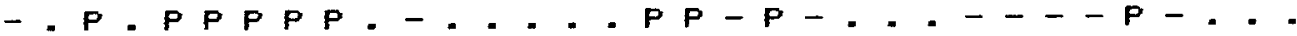
- P.PP - - P.-.....- - - - P - .. - - - - P - . .

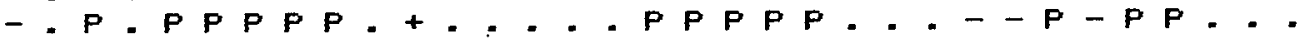

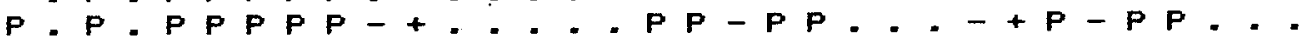

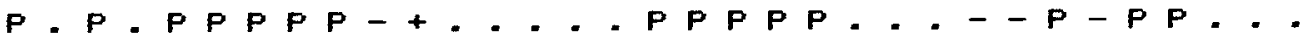

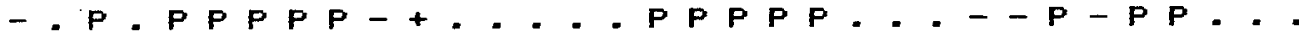
- $P$. $P P P P P-+. .-. P P-P P . . .-P P-P P . .$.

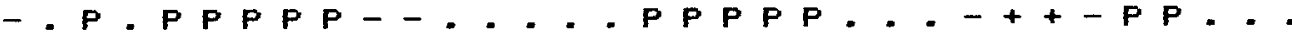

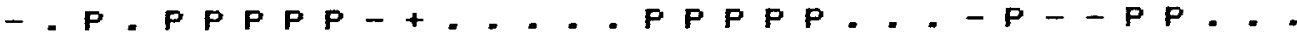

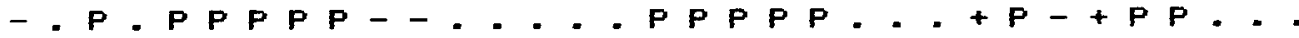

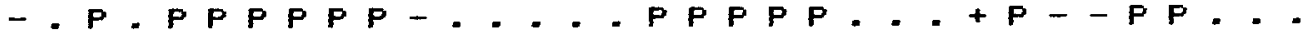

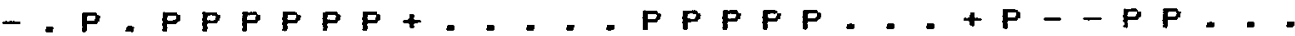

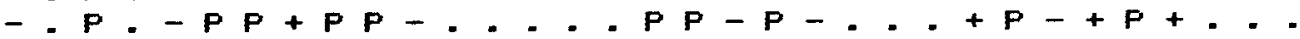

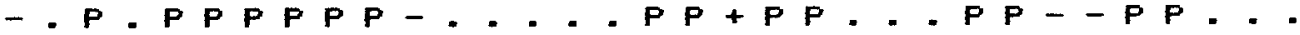

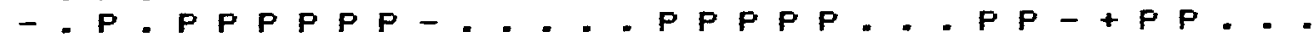

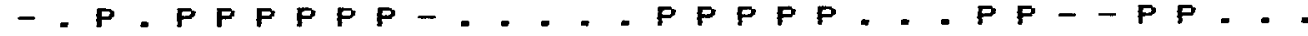

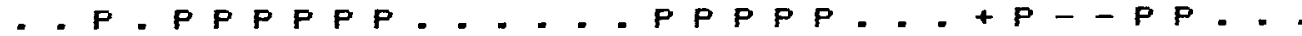

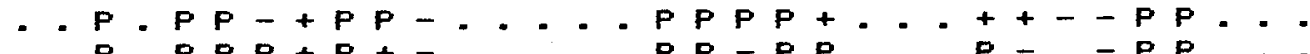

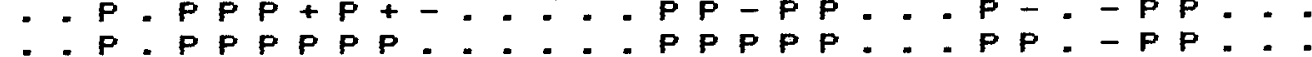




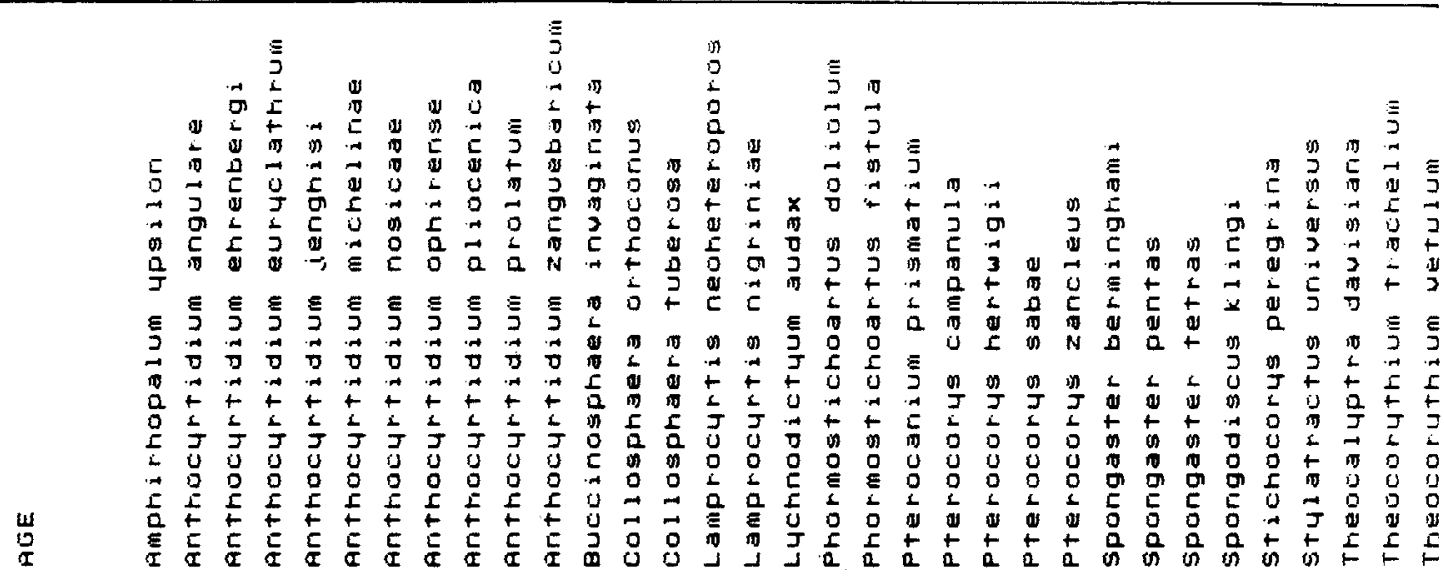

\begin{tabular}{|c|c|c|c|c|c|c|c|c|c|c|c|c|c|c|c|c|c|c|c|c|c|c|c|c|c|c|c|c|c|c|c|}
\hline 1600 & 4.07 & & & & & $P$ & $P$ & $P$ & $P$ & $\mathbf{P}$ & $=$ & - & - & & & & & $\mathbf{F}$ & - & $\mathbf{P}$ & + & & & & + & + & & & $P$ & $F$ & \\
\hline 610 & 4.08 & & $P$ & & $P$ & $\mathbf{P}$ & $P$ & $\mathbf{P}$ & $P$ & - & - & . & - & & & & $P$ & $\boldsymbol{F}$ & - & $\mathbf{P}$ & $\mathbf{P}$ & & & & $P$ & + & & - & $P$ & $\mathbf{P}$ & - \\
\hline 620 & 4.10 & & $F$ & & $P$ & $P$ & $F$ & $P$ & $P$ & $\mathbf{P}$ & . & . & - & & & - & $P$ & $F$ & + & $\mathrm{F}$ & $\mathbf{P}$ & & & & $P$ & $P$ & & 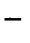 & $F$ & $P$ & - \\
\hline 1630 & 4.12 & & $-P$ & & $P$ & $\mathbf{P}$ & $\mathbf{F}$ & + & $P$ & $\mathbf{F}$ & - & - & - & & - & - & $P$ & $\mathbf{P}$ & $\mathbf{P}$ & $\mathbf{P}$ & $\mathbf{F}$ & & & & $F$ & - & & + & $\mathbf{P}$ & - & - \\
\hline 640 & 4.13 & & - $P$ & & $\mathbf{P}$ & $\mathbf{P}$ & $P$ & $\mathbf{P}$ & $\mathbf{P}$ & $P$ & - & - & - & - & & - & $P$ & $P$ & + & $F$ & $\mathbf{P}$ & & & & + & $F$ & & - & $P$ & $P$ & \\
\hline 650 & 4.15 & &.$P$ & & $P$ & $P$ & $P$ & $\mathbf{P}$ & $\mathbf{P}$ & $P$ & . & 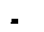 & - & & = & - & $F$ & $\mathbf{P}$ & + & $\mathbf{P}$ & $\mathbf{P}$ & & & - & + & $P$ & & $P$ & $P$ & $P$ & \\
\hline 660 & 4.16 & & $F$ & & $\mathbf{P}$ & $\mathbf{P}$ & + & $\mathbf{P}$ & $P$ & $P$ & 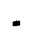 & . & - & & & . & $F$ & $\mathbf{P}$ & + & $\mathbf{P}$ & $\mathbf{P}$ & & & & $P$ & $\mathbf{P}$ & & 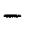 & $P$ & $F$ & \\
\hline $6 / 0$ & 4.18 & & . $P$ & & $P$ & $P$ & $\boldsymbol{F}$ & + & $P$ & $\mathbf{P}$ & - & - & - & & - & & $P$ & $\mathbf{P}$ & - & $\mathbf{P}$ & $P$ & & & & $P$ & + & & - & $P$ & 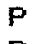 & * \\
\hline 680 & 4.19 & & $-P$ & & $P$ & $P$ & $P$ & + & $P$ & $\mathbf{P}$ & . & - & . & 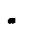 & . & * & $P$ & $P$ & - & $P$ & $P$ & & 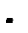 & & + & + & - & + & $P$ & $P^{*}$ & - \\
\hline 691 & 4.21 & & - $P$ & & $P$ & $P$ & $P$ & $P$ & $P$ & $P$ & . & - & $=$ & - & = & - & $F$ & $\boldsymbol{P}$ & + & $\mathbf{P}$ & $\mathbf{P}$ & & & & $P$ & $P$ & - & + & $\mathbf{P}$ & $P$ & \\
\hline 1698 & 4.22 & & $-P$ & & $\mathbf{P}$ & $\boldsymbol{P}$ & $P$ & $P$ & $\mathbf{P}$ & $P$ & - & - & - & - & . & - & $F$ & $P$ & - & $\mathbf{P}$ & $\mathbf{P}$ & & & & $P$ & + & & - & $F$ & $P$ & \\
\hline 704 & 4.23 & & $-P$ & & $\mathbf{F}$ & $P$ & $P$ & + & $P$ & $P$ & $=$ & . & 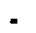 & & • & & $P$ & $P$ & - & $P$ & + & & - & & $p$ & $P$ & - & - & $P$ & $\mathbf{P}$ & \\
\hline 710 & 4.24 & & $P$ & & $F$ & $\mathbf{P}$ & + & - & $\boldsymbol{P}$ & $P$ & " & - & $=$ & & & & $P$ & $F$ & + & $\mathbf{P}$ & + & & $=$ & & $P$ & - & 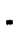 & - & $P$ & $P$ & \\
\hline 720 & 4.28 & & $-P$ & & $\mathbf{P}$ & $P$ & + & + & $P$ & $P$ & - & = & - & & & & $P$ & $P$ & + & $\mathbf{P}$ & $\mathbf{P}$ & & 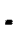 & & $P$ & - & - & + & $P$ & $\mathbf{P}$ & - \\
\hline 1730 & 4.33 & & $-F$ & & $\mathbf{P}$ & $\mathbf{P}$ & - & - & $P$ & $\mathbf{P}$ & - & - & - & & & & 5 & $\mathbf{P}$ & - & $\mathbf{F}$ & - & & & & $\boldsymbol{P}$ & - & 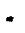 & + & $F$ & $\mathbf{P}$ & $=$ \\
\hline 1740 & 4.38 & & $=\mathbf{P}$ & & $\mathbf{P}$ & $\boldsymbol{P}$ & $\mathbf{P}$ & - & $\mathbf{P}$ & $\mathbf{P}$ & - & - & . & & - & & $P$ & $\mathbf{P}$ & $\mathbf{P}$ & $\mathbf{P}$ & $\mathbf{P}$ & & & & $P$ & - & $=$ & + & $P$ & $P$ & 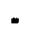 \\
\hline 1750 & 4.41 & * & $-F$ & & $P$ & $\mathbf{P}$ & - & - & $P$ & $\mathbf{P}$ & - & - & - & - & - & & $\mathbf{P}$ & $P$ & $P$ & $\mathbf{P}$ & - & & 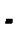 & & $P$ & - & $=$ & - & $P$ & $P$ & - \\
\hline
\end{tabular}




\section{TABLE V}

Presence of stratigraphically important radiolarians in each sample examined from core VM29-40. Ages of samples are derived from paleomagnetic calibrations of Fig. 6. Explanation of symbols in text.

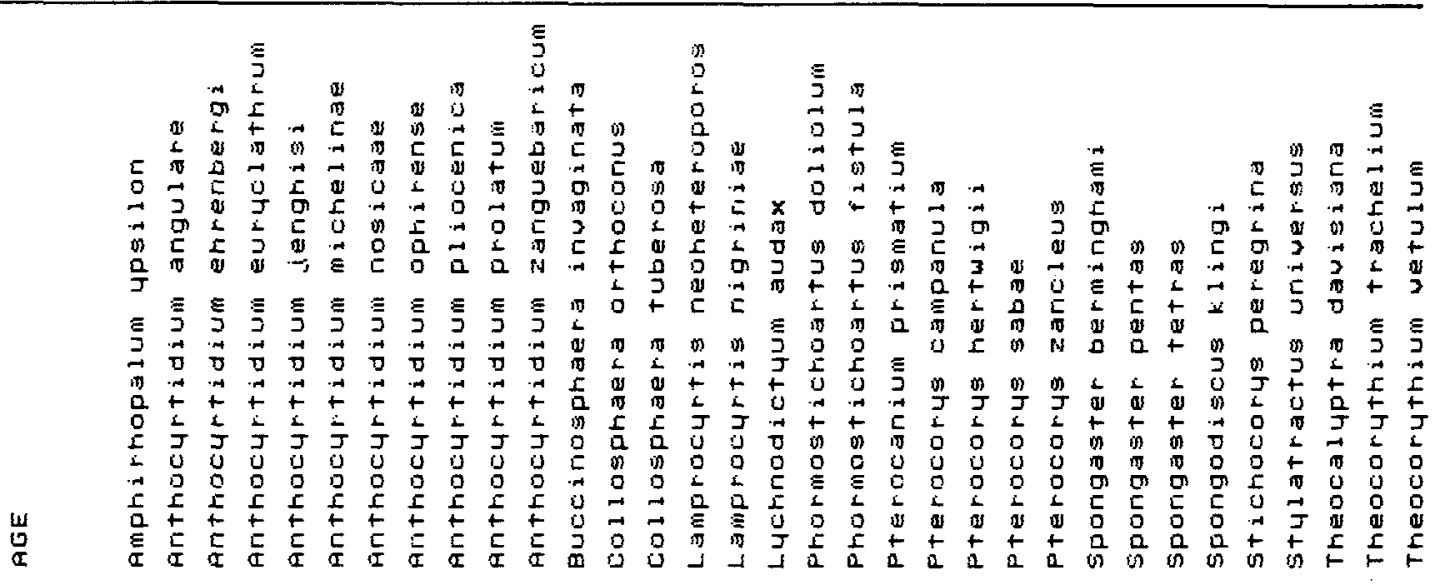

\begin{tabular}{|c|c|c|c|c|c|c|c|c|c|c|c|c|c|c|c|c|c|c|c|c|c|c|c|c|c|c|c|c|c|c|}
\hline 2 & 22 & 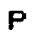 & - & $\Rightarrow$ & $P^{*}$ & $\mathbf{P}$ & $\mathbf{P}$ & - & • & $P$ & & & - & -- & - & - & • & $\mathbf{P}$ & $\mathbf{P}$ & - & * & - & - & & & & & 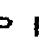 & & - \\
\hline 045 & 2.30 & $P$ & - & - & $\mathbf{P}$ & $\mathbf{P}$ & $\mathbf{P}$ & - & . & $\mathbf{P}$ & & & . & - & & 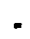 & . & $\mathbf{P}$ & $\mathbf{P}$ & . & . & . & 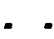 & & $P$ & - & & p & $P$ & \\
\hline 083 & - 38 & $\mathbf{P}$ & - & - $P$ & $P$ & $\mathbf{P}$ & $\mathbf{P}$ & & 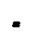 & - & & & . & - & & & . & $\mathbf{P}$ & $\mathbf{P}$ & & $=$ & - & & & D & $=$ & & & $P$ & \\
\hline 11 & .46 & $P$ & & - $P$ & $\mathbf{P}$ & $\mathbf{P}$ & $\mathbf{P}$ & & - & $\mathbf{P}$ & & & - & $P$ & & & . & $\mathbf{P}$ & $\mathbf{P}$ & & & & & & 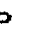 & - & & & $P$ & 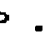 \\
\hline 144 & 54 & $\mathbf{P}$ & &.$P$ & + & $\mathbf{P}$ & & " & . & + & & & . & - & 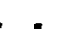 & $=$ & 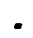 & $P$ & $P$ & 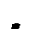 & - & . & - & & 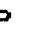 & . & & $P$ & - & - \\
\hline 183 & 62 & $\mathbf{P}$ & & . $P$ & $P$ & $P$ & $P$ & & 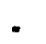 & - & & & 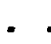 & - & . & & - & $P$ & $=$ & . & 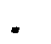 & - & - & & ? & - & & & - & - \\
\hline 0 & 70 & $P$ & . & - $P$ & $\mathbf{P}$ & $\mathbf{P}$ & $P$ & & . & $\mathbf{P}$ & & & & & & & 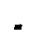 & $P$ & $\mathbf{P}$ & & & & . & & $P$ & - & & & . & - \\
\hline 244 & 8 & 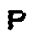 & - & - $P$ & $\mathbf{P}$ & $\mathbf{P}$ & $\mathbf{P}$ & & 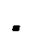 & $P$ & & & . & . & . & & - & $\mathbf{P}$ & $\mathbf{P}$ & & & & & & $\boldsymbol{P}$ & - & & + & & $?$ \\
\hline 280 & 6 & 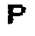 & $=-$ & . $P$ & $P$ & $\mathbf{P}$ & $\mathbf{P}$ & & - & - & & & . & . & - & & - & $\mathbf{P}$ & $\mathbf{P}$ & & 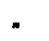 & . & - & & P & . & & P & & 一 \\
\hline 310 & 3 & 3 & $?$ & - $\mathbf{P}$ & $\mathbf{P}$ & $\mathbf{P}$ & $P$ & & - & $P$ & & & . & - & $\mathbf{P}$ & & . & $\mathbf{P}$ & - & - & - & - & - & & 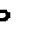 & - & & $?$ & & $=$ \\
\hline 344 & 0 & $\mathbf{P}$ & . ? & - $P$ & $\mathbf{P}$ & $\mathbf{P}$ & $\mathbf{P}$ & & 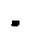 & $\mathbf{P}$ & & & . & - & + & & . & $\mathbf{P}$ & $\mathbf{P}$ & & . & & & & D & . & & . & & ? \\
\hline 375 & 8 & $\mathbf{P}$ & ? & - $P$ & $\mathbf{P}$ & $\mathbf{P}$ & $P$ & & 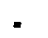 & - & & & & & ?" & & . & $\mathbf{P}$ & - & & - & & & & 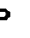 & . & & - & & - \\
\hline 412 & 16 & ? & . $\mathbf{P}$ & - $P$ & $\mathbf{P}$ & $P$ & $P$ & 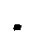 & . & $P$ & & & 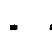 & . & + & & - & $\mathbf{P}$ & $P$ & - & & & & & $P$ & . & & - & & 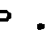 \\
\hline 5 & 3 & 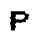 & . $P$ & - $P$ & $\mathbf{P}$ & $\mathbf{P}$ & $\mathbf{P}$ & - & - & " & $=$ & 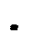 & - & - & + & 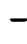 & + & $P$ & $P$ & - & $=$ & & $=$ & & $P$ & - & & - & F & 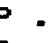 \\
\hline $\mathbf{4 8 5}$ & 0 & $\mathbf{P}$ & $P$ & - $P$ & $\mathbf{P}$ & $\mathbf{P}$ & $P$ & - & 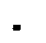 & - & • & 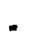 & - & - & $P$ & - & $P$ & $\mathbf{P}$ & - & 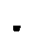 & - & - & & & $P$ & - & & 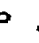 & & P \\
\hline 511 & 3.37 & $\mathbf{P}$ & $P$ & - & $\mathbf{P}$ & $\boldsymbol{P}$ & $\mathbf{P}$ & $P$ & - & - & - & - & 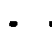 & & - & - & $P$ & $P$ & $P$ & . & - & $=$ & - & & 5 & - & & 一 & & 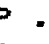 \\
\hline 545 & 3.44 & $\mathbf{P}$ & - $P$ & - $\mathbf{P}$ & $\mathbf{P}$ & $\mathbf{P}$ & $P$ & $P$ & . & - & - & - & - & & + & - & - & - & $P$ & 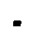 & - & $=$ & & & 9 & - & & 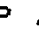 & & + \\
\hline 585 & 3.51 & - & - $P$ & - $P$ & $\mathbf{P}$ & $P$ & $P$ & $P$ & 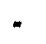 & & & & & & $\mathbf{P}$ & 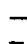 & - & + & - & - & & & & & 2 & - & & 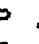 & & + \\
\hline 611 & 8 & $\mathbf{P}$ & $\mathbf{P}$ & $P$ & $\mathbf{P}$ & $P$ & $\mathbf{P}$ & $P$ & - & - & - & & & & - $P$ & $P$ & - & $P$ & - & $=$ & & . & - & & 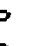 & - & & 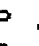 & & + \\
\hline 64 & 3.66 & $P$ & . $P$ & - & $\mathbf{P}$ & $P$ & $P$ & + & . & $P$ & - & - & 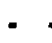 & & $\mathbf{P}$ & $P$ & - & - & - & - & $=$ & - & - & & 5 & - $F$ & & o & $t$ & + \\
\hline 685 & .74 & $P$ & $-P$ & - $P$ & $\mathbf{P}$ & $P$ & - & $\boldsymbol{P}$ & - & - & . & - & 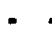 & & $P$ & $P$ & $P$ & $\boldsymbol{P}$ & - & - & - & & - & & 0 & $-F$ & & 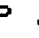 & • & 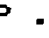 \\
\hline 7 & -8 & $P$ & $F$ & $-P$ & $P$ & $P$ & $P$ & $P$ & \pm & $P$ & - & - & - & & - $P$ & & $P$ & $\mathbf{P}$ & - & - & - & & $-F$ & & - & - & & 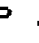 & & - \\
\hline $74 t$ & .9 & - & - $P$ & - $P$ & $P$ & $P$ & $P$ & $\mathbf{P}$ & $P$ & $P$ & • & & & & - $P$ & & $P$ & - & - & 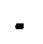 & 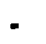 & & $+P$ & & + & $P$ & & - & - & $?$ \\
\hline 783 & 4.00 & - & $-P$ & $P$ & $\mathbf{P}$ & $P$ & $P$ & $P$ & $P$ & $P$ & - & - & - & . & - $P$ & & + & $P$ & $P$ & & - & . & - & & - & $-F$ & & 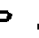 & & \\
\hline
\end{tabular}




\section{TABLE VI}

Listing of sub-bottom depths and estimated ages of radiolarian events in each of the four "type-section" cores from the Indian Ocean. Ages of events in these cores are shown to two decimal places, due to the relatively high stratigraphic precision obtained via isotopic and/or paleomagnetic calibrations (Figs. 2 through 6). Right-hand columns list the estimated ages of these events in DSDP Sites from the equatorial Indian and Pacific Ocean (Johnson and Nigrini, 1985), in order to assess the relative synchroneity of each event (see Table VII).

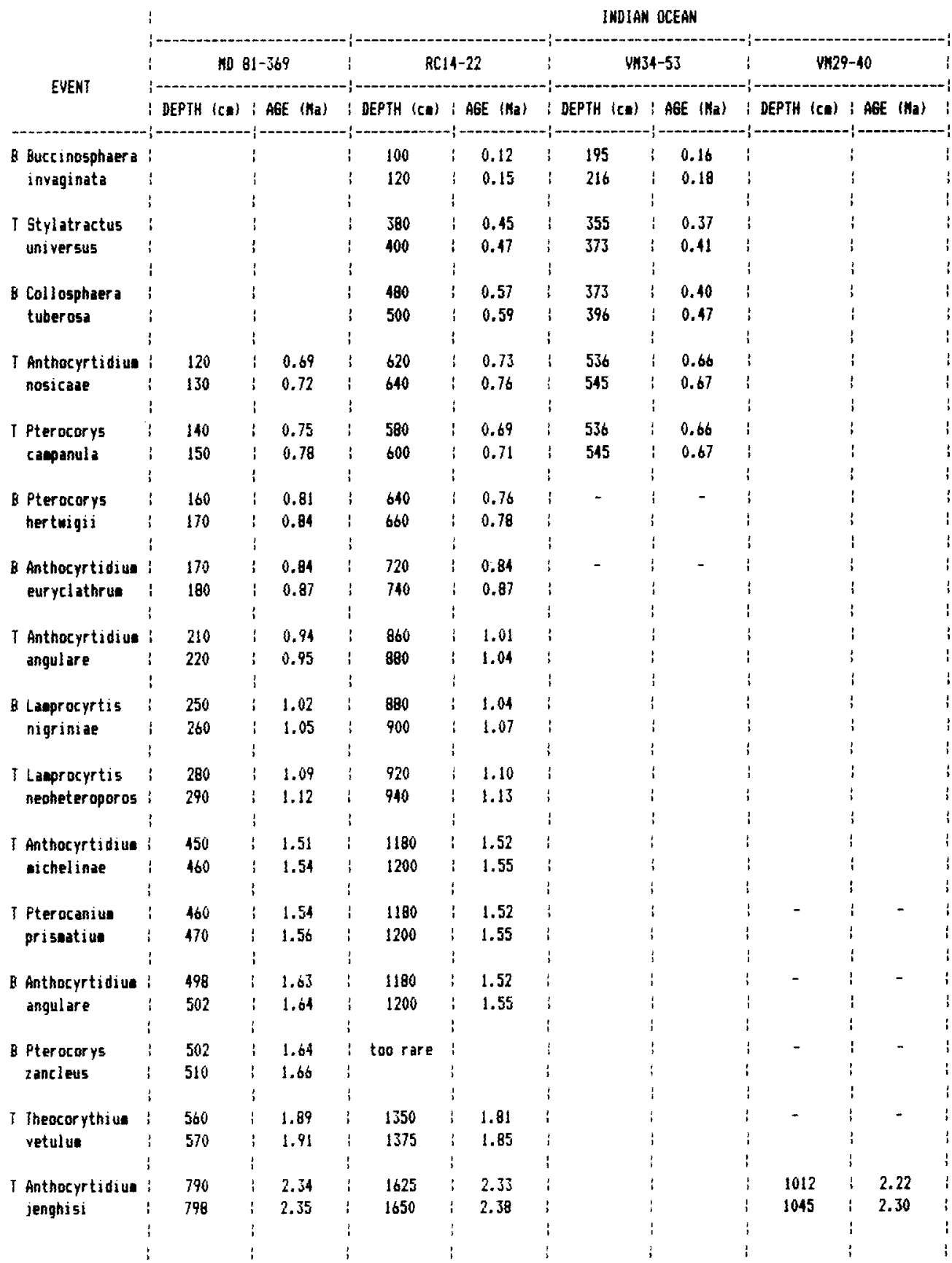


TABLE VI (continued)

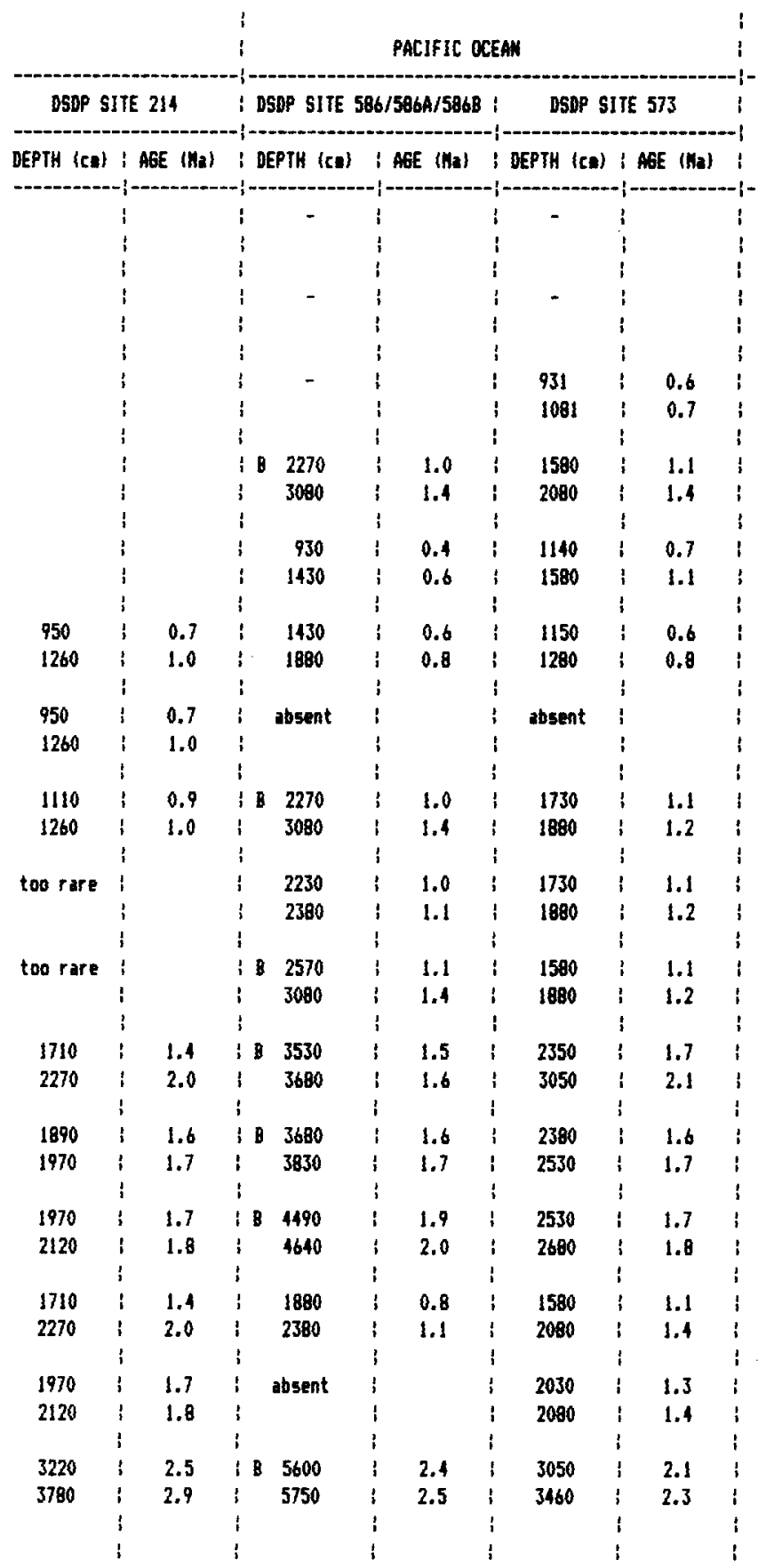




\begin{tabular}{|c|c|c|c|c|}
\hline \multirow{3}{*}{$\begin{array}{l}\text { Theocalyptra } \\
\text { davisiand }\end{array}$} & i & B30 & i & 2.12 \\
\hline & 1 & 840 & i & 2.44 \\
\hline & & & 1 & \\
\hline \multirow{2}{*}{$\begin{array}{l}\text { L Lasprocyrtis } \\
\text { neoheteroporos }\end{array}$} & 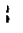 & 970 & i & 2.51 \\
\hline & 1 & 890 & $i$ & 2.53 \\
\hline \multirow{2}{*}{$\begin{array}{l}\text { Theocorythius } \\
\text { tracheliun }\end{array}$} & : & 880 & 1 & 2.54 \\
\hline & 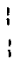 & 890 & ; & 2.56 \\
\hline \multirow{2}{*}{$\begin{array}{l}\text { I Stichocorys } \\
\text { peregrina }\end{array}$} & $i$ & 910 & i & 2.82 \\
\hline & i & 920 & $i$ & 2.64 \\
\hline \multirow{3}{*}{$\begin{array}{l}\text { I Anthocyrtidiun } \\
\text { ehrenbergi }\end{array}$} & 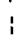 & 990 & $i$ & 2.83 \\
\hline & i & 1000 & $i$ & 2.85 \\
\hline & i & & i & \\
\hline \multirow{3}{*}{$\begin{array}{l}\text { I Anthacyrtidius } \\
\text { pliocenica }\end{array}$} & i & 1160 & ; & 3.24 \\
\hline & $:$ & 1170 & $\mathrm{i}$ & 3.26 \\
\hline & i & & i & \\
\hline \multirow{3}{*}{$\begin{array}{l}\text { IPh'stichoartus } \\
\text { fistula }\end{array}$} & : & 1170 & i & 3.26 \\
\hline & : & 1180 & : & 3.28 \\
\hline & $i$ & & $i$ & \\
\hline \multirow{3}{*}{$\begin{array}{l}\text { Tlychnodictyue } \\
\text { sudax }\end{array}$} & i & 1210 & $i$ & 3.33 \\
\hline & i & 1220 & i & 3.35 \\
\hline & i & & 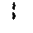 & \\
\hline \multirow{3}{*}{$\begin{array}{l}\text { I Ph'stichoartus } \\
\text { doliolus }\end{array}$} & i & 1320 & $i$ & 3.53 \\
\hline & : & 1330 & $i$ & 3.55 \\
\hline & i & & 1 & \\
\hline \multirow{3}{*}{$\begin{array}{l}\text { Aaphirhopalun } \\
\text { ypsilon }\end{array}$} & ; & 1450 & $i$ & 3.77 \\
\hline & $i$ & 1460 & : & 3.79 \\
\hline & : & & 1 & \\
\hline \multirow{3}{*}{$\begin{array}{l}\text { I Spongaster } \\
\text { pentas }\end{array}$} & : & 1460 & : & 3.79 \\
\hline & ; & 1470 & ! & 3.81 \\
\hline & i & & i & \\
\hline \multirow{3}{*}{$\begin{array}{l}\text { B Spongaster } \\
\text { tetras }\end{array}$} & ! & 1480 & 1 & 3.83 \\
\hline & 1 & 1490 & $\mathrm{t}$ & 3.85 \\
\hline & : & & $i$ & \\
\hline \multirow{3}{*}{$\begin{array}{l}\text { T Spangodicus } \\
\text { klingi (rate) }\end{array}$} & i & 1490 & i & 3.85 \\
\hline & i & 1500 & 1 & 3.87 \\
\hline & i & & : & \\
\hline \multirow{3}{*}{$\begin{array}{l}\text { I Spongaster } \\
\text { berminghani }\end{array}$} & i & 1490 & $i$ & 3.85 \\
\hline & $i$ & 1500 & : & 3.87 \\
\hline & i & & 1 & \\
\hline \multirow{3}{*}{$\begin{array}{l}\text { T Anthocyrtidiue } \\
\text { prolatus }\end{array}$} & i & 1500 & 1 & 3.87 \\
\hline & ! & 1510 & $i$ & 3.89 \\
\hline & $i$ & & : & \\
\hline \multirow{3}{*}{$\begin{array}{l}\text { Spongaster } \\
\text { pentas }\end{array}$} & $i$ & 1704 & i & 4.23 \\
\hline & i & 1710 & i & 4.24 \\
\hline & 4 & & $i$ & \\
\hline \multirow{2}{*}{$\begin{array}{l}\text { E. Anthocyptidiu } \\
\text { ophirense }\end{array}$} & & 1704 & : & 4.23 \\
\hline & i & 1710 & i & 4.24 \\
\hline
\end{tabular}




\begin{tabular}{|c|c|c|c|c|c|c|c|c|c|c|}
\hline & : & & 18 & 5300 & i & 2.3 & i & 3310 & ; & 2.2 \\
\hline & : & & : & 5450 & i & 2.4 & 1 & 3460 & 1 & 2.3 \\
\hline & i & & i & & 1 & & $i$ & & ! & \\
\hline \multirow[t]{3}{*}{ too rare } & 1 & & $: B$ & 6560 & : & 2.9 & ! & 4340 & 1 & 3.0 \\
\hline & 1 & & 1 & 6710 & 1 & 3.0 & 1 & 4800 & 1 & 3.3 \\
\hline & : & & $\mathbf{i}$ & & 1 & & 1 & & ; & \\
\hline 3070 & i & 2.4 & i & 3180 & i & 1.4 & i & 2090 & 1 & 1.4 \\
\hline \multirow[t]{2}{*}{3220} & $i$ & 2.5 & $i$ & 3330 & i & 1.5 & 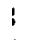 & 2230 & i & 1.5 \\
\hline & i & & : & & 1 & & $i$ & & , & \\
\hline 3520 & i & 2.6 & I & 5690 & 1 & 2.5 & 1 & 3760 & i & 2.6 \\
\hline \multirow[t]{2}{*}{3620} & $i$ & 2.7 & $i$ & 5900 & 1 & 2.6 & i & 3890 & 1 & 2.7 \\
\hline & i & & $i$ & & $i$ & & $:$ & & 1 & \\
\hline 4740 & $i$ & 3.3 & 18 & 6920 & $!$ & 3.0 & $i$ & 5210 & $i$ & 3.6 \\
\hline \multirow[t]{2}{*}{5120} & $i$ & 3.5 & i & 7220 & i & 3.3 & 1 & 5710 & 1 & 3.9 \\
\hline & $\mathrm{i}$ & & $i$ & & $!$ & & i & & 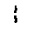 & \\
\hline 4740 & 1 & 3.3 & $1 A$ & 5690 & 1 & 2.5 & 1 & 3460 & i & 2.3 \\
\hline \multirow[t]{2}{*}{5120} & $\vdots$ & 3.5 & : & 6200 & $!$ & 2.7 & 1 & 3930 & 1 & 2.7 \\
\hline & 1 & & i & & i & & i & & $i$ & \\
\hline 4740 & i & 3.3 & IA & 7160 & i & 3.1 & ! & 1780 & $i$ & 3.1 \\
\hline \multirow[t]{2}{*}{4820} & $i$ & 3.4 & ! & 7310 & ! & 3.2 & $i$ & 4800 & $!$ & 3.2 \\
\hline & i & & 1 & & ! & & : & & 1 & \\
\hline 4740 & $i$ & 3.3 & IA & 8270 & 1 & 3.4 & 1 & too pare & 1 & \\
\hline \multirow[t]{2}{*}{4820} & ! & 3.1 & $!$ & 8420 & i & 3.5 & $i$ & & i & \\
\hline & i & & i & & : & & i & & 1 & \\
\hline 4920 & ! & 3.4 & IA & 8780 & i & 3.5 & i & 5060 & $i$ & 3.5 \\
\hline \multirow[t]{2}{*}{4970} & : & 3.5 & : & 8930 & 1 & 3.6 & $i$ & 5210 & i & 3.6 \\
\hline & $i$ & & i & & : & & $i$ & & 1 & \\
\hline 5690 & $i$ & 3.6 & IA & 8780 & 1 & 3.5 & ! & 5360 & 1 & 3.7 \\
\hline \multirow[t]{2}{*}{5770} & ! & 3.7 & $i$ & 8930 & i & 3.6 & $!$ & 5510 & 1 & 3.8 \\
\hline & : & & ! & & 1 & & ! & & ! & \\
\hline 5120 & ; & 3.2 & : A & 8570 & ; & 3.4 & $\mathrm{i}$ & 4780 & : & 3.0 \\
\hline \multirow[t]{2}{*}{5270} & 1 & 3.3 & $i$ & 8780 & ! & 3.5 & ! & 4800 & 1 & 3.1 \\
\hline & $:$ & & 1 & & 1 & & $\mathbf{i}$ & & ! & \\
\hline 5270 & : & 3.6 & IA & 9530 & i & 3.6 & i & 5510 & : & 3.8 \\
\hline \multirow[t]{5}{*}{5690} & i & 3.7 & i & 9740 & i & 3.7 & i & 5660 & ! & 3.9 \\
\hline & 1 & & 1 & & $!$ & & i & & $\vdots$ & \\
\hline & i & & 18 & 10290 & ! & 3.8 & $i$ & & 1 & \\
\hline & $i$ & & 1 & 10650 & $i$ & 3.9 & $i$ & & i & \\
\hline & ; & & $i$ & & i & & 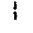 & & $i$ & \\
\hline 6520 & $i$ & 3.8 & IA & 12920 & $!$ & 4.2 & i & 6670 & ! & 4.5 \\
\hline \multirow[t]{2}{*}{6640} & $i$ & 3.9 & i & 13070 & i & 4.3 & $\mathrm{i}$ & 6740 & i & 4.6 \\
\hline & i & & i & & : & & : & & 1 & \\
\hline 6070 & $i$ & 3.8 & ; 8 & 11100 & ; & 3.9 & $i$ & absent & i & \\
\hline \multirow[t]{2}{*}{$66 \pm 0$} & i & 3.9 & i & 11250 & ; & 1.0 & : & & i & \\
\hline & i & & i & & i & & 1 & & : & \\
\hline 7670 & : & 4.2 & IA & 13580 & 1 & 4.3 & ! & 7620 & $i$ & 5.0 \\
\hline \multirow[t]{2}{*}{7820} & : & 4.3 & i & 13730 & i & 4.4 & i & 7690 & i & 5.1 \\
\hline & i & & i & & : & & : & & i & \\
\hline 5690 & 1 & 3.7 & 18 & 15750 & ; & 4.9 & $i$ & 7620 & $i$ & 5.1 \\
\hline 6070 & : & 3.8 & ! & 16410 & : & 5.0 & 1 & 7990 & i & 5.2 \\
\hline
\end{tabular}




\section{TABLE VII}

Listing of time-transgressive Pliocene-Pleistocene radiolarian events in the tropical Indian/Pacific Oceans. Events are considered time-transgressive if the difference in their estimated ages exceeds $0.4 \mathrm{~m}$.y. between the Indian and Pacific (see Table VI). Other events may also be time-transgressive, but by amounts less than $0.4 \mathrm{~m} . \mathrm{y}$.

\begin{tabular}{lll}
\hline Event & Estimated age (Ma) \\
\hline & $\begin{array}{l}\text { Indian Ocean } \\
\text { (this study) }\end{array}$ & $\begin{array}{l}\text { Central Pacific } \\
\text { (Johnson and Nigrini, 1985) }\end{array}$ \\
A. Last occurrences & & \\
Tm Anthocyrtidium nosicaae & $0.66-0.76$ & $1.1-1.4$ \\
Tm Anthocyrtidium michelinae & $1.51-1.55$ & $1.7-2.1$ \\
Tm Theocorythium vetulum & $1.81-1.91$ & $1.3-1.4$ \\
Tm Anthocyrtidium ehrenbergi & $2.83-2.93$ & $3.6-3.9$ \\
Tm Anthocyrtidium pliocenica & $3.24-3.37$ & $2.3-2.7$ \\
Tm Spongaster pentas & $3.74-3.82$ & $4.5-4.6$ \\
Tm Spongaster berminghami & $3.85-3.87$ & $4.5-4.6$ \\
& & \\
B. First occurences & & \\
Bm Pterocorys zancleus & $1.64-1.66$ & $0.8-1.4$ \\
Bm Lamprocyrtis neoheteroporos & $2.46-2.53$ & $3.0-3.3$ \\
Bm Theocorythium trachelium & $2.46-2.56$ & $1.4-1.5$ \\
Bm Spongaster pentas & $4.23-4.24$ & $5.0-5.1$ \\
Bm Anthocyrtidium ophirense & $4.23-4.24$ & $5.1-5.2$ \\
\hline
\end{tabular}

\section{Appendix: Taxonomic concepts of strati- graphically important radiolarians}

In this section we list the complete taxonomic name of each radiolarian species included in this study. We also indicate a recent reference containing species descriptions and photographs of representative specimens.

Acrosphaera spinosa (Haeckel) hamospina Caulet, 1986a, p. 848 , pl. 1, figs. 2,3 .

Amphirhopalum ypsilon Haeckel, 1887, p. 522; Nigrini, 1967, p. 35, pl. 3, figs. 3a-d; Nigrini, 1971, p. 447, pl. 34.1, figs. 7a-c.

Anthocyrtidium angulare Nigrini, 1971, p. 445, pl. 34.1, figs. 3a,b; Nigrini and Caulet, 1988, p. 343, pl. 1, figs. 1, 2.

Anthocyrtidium ehrenbergi (Stöhr). Anthocyrtis ehrenbergi in Stohr, 1880, p. 100, pl. 3, figs. 21a,b and in Nigrini and Caulet, 1988, p. 345, pl. 1, figs. 3, 4.

Anthocyrtidium euryclathrum Nigrini and Caulet, in press. Anthocyrtidium jenghisi Streeter, 1988, p. 63, pl. 1, figs. 14.; Nigrini and Caulet, 1988, p. 345, pl. 1, figs. 3, 4.

Anthocyrtidium michelinae Caulet, 1979, p. 132, pl. 2, figs. 8, 9; Nigrini and Caulet, 1988, p. 349, pl. 1, figs. 5-7.

Anthocyrtidium nosicaae Caulet, 1979, p. 132, pl. 2, fig. 6; Nigrini and Caulet, 1988, p. 351, pl. 1, figs. 15-17.
Anthocyrtidium ophirense (Ehrenberg), Ehrenberg, 1872a, p. 301,1872 b, p. 285 , pl. 9 , fig. 14; Nigrini, 1967, p. 56 , pl. 6, fig. 3; Nigrini and Caulet, 1988, p. 352, pl. 2, figs. $1-4$.

Anthocyrtidium pliocenica (Seguenza). Anthocyrtis ehrenbergi Stohr var. pliocenica Seguenza, in Stohr, 1880 , p. 232; Nigrini and Caulet, 1988, p. 355, pl. 2, figs. 5,6 .

Anthocyrtidium prolatum Nigrini and Caulet, 1988, p. 355 , pl. 2, figs. 5, 6 .

Anthocyrtidium zanguebaricum (Ehrenberg). Anthocyrtis zanguebarica in Ehrenberg, 1872a, p. 301, 1872b, pl. 9 , fig. 12; Nigrini, 1967 , p. 58, pl. 6, fig. 4; Nigrini and Caulet, 1988, p. 355, pl. 2, fig. 11.

Buccinosphaera invaginata Haeckel, 1887, p. 99, pl. 5, fig. 11; Nigrini, 1971, p. 445 , pl. 34.1, fig. 2.

Collosphaera orthoconus (Haeckel), 1887, p. 221, pl. 12, fig. 2; Collosphaera sp. A in Knoll and Johnson, 1975, p. 63, pl 1, figs. 1, 2, 7; pl. 2, figs. 4-6; Collosphaera or thoconus in Bjorklund and Goll, 1979, p. 1317.

Collosphaera tubercosa Haeckel, 1887, p. 97; Nigrini, 1971, p. 445 , pl. 34.1 , fig. 1 .

Lamprocyrtis neoheteroporos Kling, 1973, p. 639, pl. 5, figs. 17,18 , pl. 15, figs. 4,5 .

Lamprocyrtis nigriniae (Caulet), Conarachnium nigriniae in Caulet, 1971, p. 3, pl. 3, figs. 1-4, Lamprocyrtis nigriniae (Caulet) in Kling, 1977, p. 217, pl. 1, fig. 17.

Lychnodictyum audax Riedel, 1953, p. 810, pl. 85, fig. 9. 
Phormostichoartus doliolum (Riedel and Sanfilippo), Artostrobium doliolum in Riedel and Sanfilippo, 1971, p. 1599, pl. 1H, figs. 1-3, pl. 8, figs. 14, 15; Phormostichoartus doliolum (Riedel and Sanfilippo) in Nigrini, 1977 , p. 252, pl. 1, fig. 14.

Phormostichoartus fistula Nigrini, 1977, p. 253, pl. 1, figs. 11-13.

Pterocanium prismatium Riedel, 1957, p. 87, pl. 3, figs. 4, 5; emend. Riedel and Sanfilippo, 1970, p. 529.

Pterocorys campanula Haeckel, 1887, p. 1316, pl. 71, fig. 3; Caulet and Nigrini, 1988, p. 226, pl. 1, figs. 2-5.

Pterocorys hertwigii (Haeckel). Eucyrtidium hertwigii in Haeckel, 1887, p. 1491, pl. 80, fig. 12; Pterocorys hertwigii (Haeckel) in Nigrini, 1967, p. 73, pl. 6, figs. 4a,b; Caulet and Nigrini, 1988, p. 229, pl. 1, figs. 11, 12.

Pterocorys sabae (Ehrenberg), Pterocanium sabae in Ehrenberg, 1872a, p. 319; 1872b, p. 299, pl. 10, fig. 17; Pterocorys sabae (Ehrenberg) in Johnson and Nigrini, 1980, pl. 150, pl. IV, fig. 2, pl. V, figs. 4, 5; Caulet and Nigrini, 1988, p. 231, pl. 2, figs. 7, 8.

Pterocorys zancleus (Mueller). Eucyrtidium zanclaeum in Mueller, 1855, p. 672; 1858, p. 41, pl. 6, figs. 1-3; Theoconus zancleus (Mueller) in Benson, 1966, p. 482, pl. 33, fig. 4, (non fig. 5); Pterocorys zancleus (Mueller) in Caulet and Nigrini, 1988, p. 231, pl. 2, figs. 10, 11.

Spongaster berminghami (Campbell and Clark). Spongastericus berminghami in Campbell and Clark, 1944, p. 30, pl. 5, figs. 1, 2; Spongaster klingi in Riedel and Sanfilippo, 1971, p. 1589, pl. 10, figs. 8-10, pl. 4, figs. 7, 8; Spongaster berminghami (Campbell and Clark) in Riedel and Sanfilippo, 1978, p. 73, pl. 2, figs. 14-16.

Spongaster pentas Riedel and Sanfilippo, 1970, p. 523, pl. 15 , fig. 3.

Spongaster tetras Ehrenberg, 1860, p. 833; Spongaster tetras tetras Ehrenberg in Nigrini, 1967, p. 41, pl. 5, figs. $1 \mathrm{a}, \mathrm{b}$.

Spongodiscus klingi Caulet, 1986a, p. 849, pl. 2, figs. $2,3$.

Stichocorys peregrina (Riedel), Eucyrtidium elongatum peregrinum in Riedel, 1953, p. 812, pl. 85, fig. 2; Stichocorys peregrina (Riedel) in Sanfilippo and Riedel, 1970, p. 451, pl. 1, fig. 10 .

Stylatractus universus Hays, 1970, p. 215, pl. 1, figs. $1,2$.

Theocalyptra davisiana (Ehrenberg). Cycladophora ? davisiana in Ehrenberg, 1861, p. 297; Theocalyptra davisiana (Ehrenberg) in Riedel, 1958, pl. 4, figs. 2, 3, fig. 10.

Theocorythium trachelium (Ehrenberg). Eucyrtidium trachelius in Ehrenberg, 1872a, p. 312; 1872b, pl. 7, fig. 8; Theocorythium trachelium trachelium (Ehrenberg) in Nigrini, 1967, p. 79, pl. 8, fig. 2, pl. 9, fig. 2.

Theocorythium vetulum Nigrini, 1971, p. 447, pl. 34.1, figs. $6 a, b$.

\section{References}

Backman, J. and Shackleton, N.J., 1983. Quantitative biochronology of Pliocene and early Pleistocene calcareous nannofossils from the Atlantic, Indian and Pacific Oceans. Mar. Micropaleontol., 8: 141-170.

Baker, C.W., 1983. Evolution and hybridization in the radiolarian genera Theocorythium and Lamprocyclas. $\mathrm{Pa}$ leobiology, 9: 341-354.

Baldauf, J.G., Thomas, E., Clement, B., Takayama, T., Weaver, P.P.E., Backman, J., Jenkins, G., Mudie, P.J. and Westberg Smith, M.J., 1986. Magnetostratigraphic and biostratigraphic synthesis, Deep Sea Drilling Project Leg 94. In: Initial Reports of the Deep Sea Drilling Project, 94. U.S. Government Printing Office, Washington, D.C., pp. 1159-1205.

Barron, J.A., Nigrini, C.A., Pujos, A., Saito, T., Theyer, F., Thomas, E. and Weinreich, N., 1985. Synthesis of biostratigraphy; central equatorial Pacific, Deep Sea Drilling Project, leg 85: Refinement of Oligocene to Quaternary biochronology. In: L. Mayer, F. Theyer et al., Initial Reports of the Deep Sea Drilling Project, 85. U.S. Govermment Printing Office, Washington, D.C., pp. 905-934.

Benson, R.N., 1966. Recent Radiolaria from the Gulf of California Thesis, Univ. Minnesota, Minneapolis, 577 pp.

Berggren, W.A., Burckle, L.H., Cita, M.B., Cooke, H.B.S., Funnell, B.M., Gartner, S., Hays, J.D., Kennett, J.P., Opdyke, N.D., Pastouret, L., Shackleton, N.J. and Takayanagi, Y., 1980. Towards a Quaternary time scale. Quat. Res., 13: 277-302.

Berggren, W.A., Kent, D.V., Flynn, J.J. and Van Couvering, J.A., 1985a. Cenozoic geochronology. Geol. Soc. Am. Bull., 96: 1407-1418.

Berggren, W.A., Kent, D.V. and Van Couvering, J.A., $1985 b$. The Neogene: Part 2. Neogene geochronology and chronostratigraphy, In: The Chronology of the Geological Record, N.J. Snelling, (Editor), Geol. Soc. London Mem. 10, pp. 211-260.

Bjørklund, K.R. and Goll, R.M., 1979. Internal skeletal structures of Collosphaera and Trisolenia: a case of repetitive evolution in the Collosphaeridae (Radiolaria). J. Paleontol., 53: 1293-1326.

Burckle, L.H., 1977. Pliocene and Pleistocene diatom datum levels from the equatorial Pacific. Quat. Res., 7:330340.

Burckle, L.H. and Opdyke, N.D., 1977. Late Neogene diatom correlations in the circum-Pacific. Proc. First Int. Congr. Pacific Neogene Stratigraphy, Tokyo, pp. 255284.

Campbell, A.S. and Clark, B.L., 1944. Miocene radiolarian 
faunas from southern California. Geol. Soc. Am. Spec. Paper, No. 51, pp. 1-76.

Caulet, J.P., 1971. Contribution a l'étude de quelques Radiolaires Nasselaires des boues de la Méditerranée et du Pacifique. Arch. orig. Centre de Documentation C.N.R.S., Cah. Micropaleontol. ser. 2, 10, 498, 10 pp.

Caulet, J.P., 1978. Sédimentation biosiliceuse néogène et quaternaire dans l'océan Indien. Bull. Soc. Géol. France, XX, no. 4, pp. 577-583.

Caulet, J.P., 1979. Les dépôts à Radiolaires d'age pliocène supérieur a pleistocéne dans l'océan Indien central: nouvelle zonation biostratigraphique. In: Recherches Océanographiques dans l'Océan Indien, Mém. Mus. Nat. Hist. Nat. Paris, Ser. C, 43: 119-141.

Caulet, J.P., 1982. Faunes de radiolaires et fluctuations climatiques dans les sédiments de l'océan Indien austral: une nouvelle biozonation. Bull. Soc. Géol. France, XXIV, 3, 555-562.

Caulet, J.P., Clement, P. and Milleliri, P. 1984. GEOCORES: Inventaire informatisé des roches et sédiments marins conservés au Museum national d'histoire naturelle. Bull. Mus. Nat. Hist. Paris, Sec. C, 3, pp. 215-243.

Caulet, J.P., 1986a. Radiolarians from the southwestern Pacific. In: Kennett, J.P., Von der Borch, C.C. et al., Initial Reports of the Deep Sea Drilling Project, 90. U.S. Government Printing Office, Washington, D.C., pp. 835861.

Caulet, J.P., 1986b. A refined radiolarian biostratigraphy for the Pleistocene of the temperate Indian Ocean. Mar. Micropaleontol., 11: 217-229.

Caulet, J.P. and Nigrini, C., 1988. The genus Pterocorys (Radiolaria) from the tropical late Neogene of the Indian and Pacific Oceans. Micropaleontology, 34: 217235.

Clement, B.M. and Kent, D.V., 1987. Short polarity intervals within the Matuyama: transitional field records from hydraulic piston cored sediments from the North Atlantic. Earth Planet. Sci. Lett., 81: 253-264.

Davies, T.A. and Kidd, R.B., 1977. Sedimentation in the Indian Ocean through time. In: Indian Ocean Geology and Biostratigraphy, J.R. Heirtzler et al. (Editors), Am. Geophys. Union, Washington, D.C., pp. 61-85.

Dowsett, H.J., 1987. A biochronological model for correlation of Pliocene marine sequences: application of the graphic correlation method. Thesis, Brown University, Providence, R.I., 274 pp.

Ehrenberg, C.G., 1860. Über den Tiefgrund des Stillen Ozeans zwischen Kalifornien und den Sandwich-Inseln aus bis 15600' Tiefe nach Lieut. Brookes, K. Preuss. Akad. Wiss. Berlin, Monatsber.,1860, pp. 819-833.

Ehrenberg, C.G., 1861. Über die tiefgrund-Verhältnisse des Ozeans am Eingange der Davis-strasse und Island. K. Preuss. Akad. Wiss. Berlin, Monatsber., 1861, pp. 275315.

Ehrenberg, C.G., 1872a. Mikrogeologische Studien als Zusammenfassung seiner Beobachtungen des kleinsten
Lebens der Meeres-Tiefgrunde aller Zonen und dessen geologischen Einfluss. K. Preuss. Akad. Wiss., Berlin, Monatsber., 1872, pp. 265-322.

Ehrenberg, C.G., 1872b. Mikrogeologische Studien über das kleinste Leben der Meeres-Tiefgrunde aller Zonen und dessen geologischen Einfluss. Abh. K. Akad. Wiss., Berlin, 1872, pp. 131-399.

Gartner, S., 1973. Absolute chronology of the Neogene calcareous nannofossil succession in the equatorial Pacific. Geol. Soc. Am. Bull., 84: 2021-2034.

Haeckel, E., 1887. Report on the Radiolaria collected by H.M.S. Challenger during the years 1873-1876. In: C.W. Thompson and J. Murray (Editors), The Voyage of H.M.S. Challenger, Vol. 18, H.M.S.O., London, pp. 11760 .

Haq, B.U., Worsley, T.R., Burckle, L.H., Douglas, R.G., Keigwin, L.D., Opdyke, N.D., Savin, S.M., Sommer, M.A., Vincent, E. and Woodruff, F., 1980. Late Miocene marine carbon-isotopic shift and synchroneity of some phytoplanktonic biostratigraphic events. Geology, 8: 427-431.

Haq, B.U., Hardenbol, J. and Vail, P.R., 1987. Chronology of fluctuating sea levels since the Triassic. Science, 235: 1156-1167.

Hays, J.D., 1970. Stratigraphy and evolutionary trends of Radiolaria in North Pacific deep-sea sediments. In: J.D. Hays (Editor), Geological Investigations of the North Pacific. Geol. Soc. Am. Mem., 126: 185-218.

Hays, J.D., Saito, T., Opdyke, N.D. and Burckle, L.H., 1969. Pliocene-Pleistocene sediments of the equatorial $\mathrm{Pa}$ cific: Their paleomagnetic, biostratigraphic, and climatic record. Geol. Soc. Amer. Bull., 80: 1481-1514.

Hays, J.D. and Shackleton, N.J., 1976. Globally synchronous extinction of the radiolarian Stylatractus universus. Geology, 4: 649-652.

H.D. Hedberg, (Editor) 1976. International Stratigraphic Guide. International Subcommission on Stratigraphy. Wiley, New York, vol. 5, pp. 283-295.

Johnson, D.A. and Knoll, A.H., 1975. Absolute ages of Quaternary radiolarian datum levels in the equatorial $\mathbf{P a}$ cific. Quat. Res., 5: 99-110.

Johnson, D.A. and Nigrini, C., 1980. Radiolarian biogeography in surface sediments of the western Indian Ocean. Mar. Micropaleontol., 5: 111-152.

Johnson, D.A. and Nigrini, C., 1982. Radiolarian biogeography in surface sediments of the eastern Indian Ocean. Mar. Micropaleontol., 7: 237-281.

Johnson, D.A. and Nigrini, C.A., 1985. Synchronous and timetransgressive Neogene radiolarian datum levels in the equatorial Indian and Pacific Oceans. Mar. Micropaleontol., 9: 489-523.

Keller, G. and Barron, J.A., 1981. Integrated planktic foraminiferal and diatom biochronology for the northeast Pacific and the Monterey Formation. In: R.E. Garrison and R.G. Douglas (Editors), The Monterey Formation and Related Siliceous Rocks of California. Soc. Econ. Paleontol. Mineral., Tulsa, Oklahoma, pp. 43-54. 
Kling, S.A., 1973. Radiolaria from the eastern North $\mathrm{Pa}$ cific, DSDP Leg 18. In: L.D. Kulm, R. Von Huene et al. (Editors), Initial Reports of the Deep Sea Drilling Project, 18. U.S. Government Printing Office, Washington, D.C., pp. 155-182.

Kling, S.A., 1977. Local and regional imprints on radiolarian assemblages from California coastal basin sediments. Mar. Micropaleontol., 2: 295-318.

Knoll, A.H. and Johnson, D.A., 1975. Late Pleistocene evolution of the collosphaerid radiolarian Buccinosphaera invaginata Haeckel. Micropaleontology, 21: 60-68.

Kolla, V., Be, A.W.H. and Biscaye, P.E., 1976. Calcium carbonate distribution in the surface sediments of the Indian Ocean. J. Geophys. Res., 81: 2605-2616.

Lisitzin, A.P., 1967. Basic relationships in distribution of modern siliceous sediments and their connection with climatic zonation. Int. Geol. Rev., 9: 631-652.

Lisitzin, A.P., 1972. Sedimentation in the world ocean. Soc. Econ. Paleontol. Mineral., spec. publ., 17: 218 pp.

Mankinen, E.A., Donnelly, J.M. and Gromme, C.S., 1978. Geomagnetic polarity event recorded at 1.1 m.y. B.P. on Cobb Mountain, Clear Lake volcanic field, California. Geology, 6: 653-656.

Morley, J.J. and Shackleton, N.J., 1978. Extension of the radiolarian Stylatracturs universus as a biostratigraphic datum to the Atlantic Ocean. Geology, 6: 309311.

Morley, J.J. and Hays, J.D., 1981. Towards a high-resolution, global, deep-sea chronology for the last 750,000 years. Earth Planet. Sci. Lett., 53: 279-295.

Mueller, J., 1855. Über die im Hafen von Messina beobachteten Polycystinen. Monatsber. K. Akad. Wiss. Berlin, 1855, pp. 671-674.

Mueller, J., 1858. Über die Thalassicollen, Polycystinen und Acanthometren des Mittelmeeres. K. Akad. Wiss. Berlin, Abh., 1858, pp. 1-62.

Nigrini, C., 1967. Radiolaria in pelagic sediments from the Indian and Atlantic Oceans. Bull. Scripps Inst. Oceanogr., 11: 1-125.

Nigrini, C., 1971. Radiolarian zones in the Quaternary of the equatorial Pacific Ocean. In: B.M. Funnell and W.R. Riedel (Editors), The Micropaleontology of Oceans, Cambridge University Press, pp. 443-461.

Nigrini, C., 1977. Tropical Cenozoic Artostrobiidae (Radiolaria), Micropaleontology, 23: 241-269.

Nigrini, C. and Caulet, J.P., 1988. The genus Anthocyrtidium (Radiolaria) from the tropical late Neogene of the Indian and Pacific Oceans. Micropaleontology, 34: 341360.

Opdyke, N.D., 1972. Paleomagnetism of deep-sea cores. Rev. Geophys. Space Phys., 10: 213-249.

Opdyke, N.D. and Glass, B.P., 1969. The paleomagnetism of sediment cores from the Indian Ocean. Deep-Sea Res., 16: $249-261$.

Peterson, L.C. and Prell, W.L., 1985a. Carbonate dissolution in recent sediments of the eastern equatorial Indian
Ocean: preservation patterns and carbonate loss above the lysocline. Mar. Geol., 64: 259-290.

Peterson, L.C. and Prell, W.L., 1985b. Carbonate preservation and rates of climatic change: an $800 \mathrm{kyr}$ record from the Indian Ocean. In: E. Sundquist and W. Broecker (Editors), The Carbon Cycle and Atmospheric CO2: Natural Variations Archean to Present, Am. Geophys. Union, Geophys. Monogr., 32, pp. 251-269.

Petrushevskaya, M.G., 1967. Radiolyarii otryadov Spumellaria i Nasselaria antarkticheskoi oblasti (Antarctic spumelline and nasseline radiolarians). Issled. Fauny Morei 4 (12), Rel. biol. Issled. Sov. Antarkt. Eksped. 1955-1958, 3. pp. 5-186.

Petrushevskaya, M.G., 1971. Radiolaria in the plankton and Recent sediments from the Indian Ocean and Antarctic. In: B.M. Funnell and W.R. Riedel (Editors), The Micropalaeontology of Oceans, Cambridge University Press, pp. 319-329.

Piola, A.R. and Gordon, A.L., 1984. Pacific and Indian Ocean upperlayer salinity budget. J. Phys. Oceanogr.,14: 747-753.

Prell, W.L., Imbrie, J., Martinson, D.G., Morley, J.J., Pisias, N.J., Shackleton, N.J. and Streeter, H.F., 1987. Graphic correlation of oxygen isotope stratigraphy: application to the later Quaternary. Paleoceanography, 1: 137-162.

Riedel, W.R., 1953. Mesozoic and Late Tertiary Radiolaria of Rotti. J. Paleontol., 27: 805-813.

Riedel, W.R., 1957. Radiolaria. A preliminary stratigraphy. Rep. Swed. Deep-Sea Exped. 1947-1948, 6 (3), pp. 5996.

Riedel, W.R., 1958. Radiolaria in Antarctic sediments. Rep. B.A.N.Z. Antarct. Res. Exped., Ser. B., 6 (10): 217-255.

Riedel, W.R. and Sanfilippo, A., 1970. Radiolaria, Leg 4, Deep Sea Drilling Project. In: R.G. Bader et al., Initial Reports of the Deep Sea Drilling Project, 4. U.S. Government Printing Office, Washington, D.C., pp. 503-575.

Riedel, W.R. and Sanfilippo, A., 1971. Cenozoic Radiolaria from the western tropical Pacific, Leg 7. In: E.L. Winterer et al., Initial Reports of the Deep Sea Drilling Project, 7. U.S. Government Printing Office, Washington, D.C., pp. 1529-1672.

Riedel, W.R. and Sanfilippo, A., 1978. Stratigraphy and evolution of tropical Cenozoic radiolarians. Micropaleontology, 24: 61-96.

Saito, T., Burckle, L.H. and Hays, J.D., 1975. Late Miocene to Pleistocene biostratigraphy of equatorial Pacific sediments. In: T. Saito and L.H. Burckle (Editors), Late Neogene Epoch Boundaries, Micropaleontol. Press, New York, pp. 226-244.

Sanfilippo, A., Westberg-Smith, M.J. and Riedel, W.R., 1985. Cenozoic Radiolaria. In: H.M. Bolli, J.B. Saunders and K. Perch-Nielsen (Editors), Plankton Stratigraphy, Cambridge University Press, pp. 631-713.

Schneider, D.A. and Kent, D.V., 1989. Inclination anomalies from Indian Ocean sediments and the possiblity of 
a standing nondipole field. J. Geophys. Res., 93, B10: 11621-11630.

Sclater, J.G. and Fisher, R.L., 1974. The evolution of the east central Indian Ocean, with emphasis on the tectonic setting of the Ninetyeast Ridge. Geol. Soc. Am. Bull., 85: 683-702.

Stohr, E., 1880. Die Radiolarienfauma der Grotte von Tripoti, Provinz Girgenti in Sizilien. Paleontographica, 3, 26 (2), pp. 69-124.

Streeter, L., 1988. Two species (one new) of Plio-Pleistocene Radiolaria. Micropaleontology, 33.

Takayanagi, Y., Takayama, T., Sakai, T., Oda, M. and Kato, M., 1979. Late Cenozoic micropaleontologic events in the equatorial Pacific sediments. Tohoku Univ. Sci. Rep., 2nd Ser., 49, 1, pp. 71-87.
Theyer, F., Mato, C.Y. and Hammond, S.R., 1978. Paleomagnetic and geochronologic calibration of latest $\mathrm{Oli}$ gocene to Pliocene radiolarian events, equatorial $\mathrm{Pa}$ cific. Mar. Micropaleontol., 3: 377-395.

Thierstein, H.R., Geitzenauer, K.R., Molfino, B. and Shackleton, N.J., 1977. Global synchroneity of late Quaternary coccolith datum levels: Validation by oxygen isotopes. Geology, 5: 400-404.

Weissel, J.K., Anderson, R.N. and Geller, C.A., 1980. Deformation of the Indo-Australian plate. Nature, 287: 284291.

Wyrtki, K., 1973. Physical oceanography of the Indian Ocean. In: B. Zeitzschel (Editor), The Biology of the Indian Ocean. Springer, New York, NY, pp. 18-36. 